Accepted version of : Gabbud, C., Bakker, M., Clémençon, M. and Lane, S.N., 2020. Causes of the severe loss of macrozoobenthos in Alpine streams subject to repeat hydropower flushing events. Water Resources Research, https://doi.org/10.1029/2019WR024758.

\title{
Hydropwer flushing events cause severe loss of macrozoobenthos in Alpine streams
}

$$
\text { C. Gabbud }{ }^{1} \text {, M. Bakker }{ }^{1} \text {, M. Clémençon }{ }^{1} \text {, and S. N. Lane }{ }^{1}
$$

${ }^{1}$ Institute of Earth Surface Dynamics (IDYST), University of Lausanne

Corresponding author: Chrystelle Gabbud (chrystelle.gabbud@unil.ch)

- Key points

- Flow abstraction at hydropower intakes in a glaciated stream improves downstream low flow habitat conditions compared to natural conditions

- Intake sediment flushing degrades habitat due to rapid discharge rise, increase in turbidity, reduction in euphotic depth, bed instability

- Sensitivity to flushing relates to discharge rise speed as suitable habitat moves across the floodplain faster than likely benthos migration 


\begin{abstract}
Alpine hydroelectric power exploitation often aims to increase the volume of water stored behind impoundments which may be achieved through flow abstraction and lateral transfer to storage. Intakes are designed to separate water (for transfer) from sediment which accumulates in settling basins and may be flushed sometimes multi-daily in glaciated basins. In some countries (e.g. Switzerland) intakes drain a greater basin area than impoundments yet legislation designed to improve instream ecosystems impacted by hydropower has almost entirely ignored them. Some research suggests that such streams have exceptionally low abundance and diversity of macroinvertebrates for some kilometres downstream of the intake flushing at high frequency in summer, but that populations can recover rapidly as soon as flushing frequency decreases in early autumn. However, such patterns could also result from natural flow variability, sediment transport and morphological change in glacierfed streams. Here, we combine field measurements with habitat modelling to assess the impacts of sediment flushing on macrozoobenthos as compared to what might be expected in a natural, morphologically dynamic Alpine stream. We show that water abstraction in itself could improve habitat conditions because it increases the importance of less turbid and groundwater/unregulated sources. However, intake flushing leads to short duration, sediment-laden flows that can destabilise substantial areas of the stream bed and cause rates of lateral displacement of habitat much greater than the possible response by macroinvertebrates. Our results challenge current emphasis on minimum flows in such streams and argue that much more emphasis needs to be placed on sediment management.
\end{abstract}




\section{Introduction}

The impact of changing streamflow regime on physical habitat has been the subject of numerous studies (e. g. Parasiewicz et al., 1998; Bunn \& Arthington, 2002; Poff \& Zimmerman, 2010). One of the current challenges is to optimize flow conditions to reduce the impact of flow abstraction and return on stream ecology whilst also meeting water demand. The science of the required environmental flow releases, also known as e-flows (The Brisbane Declaration, 2007), has developed to identify the management options needed to restore the ecological functions of a stream (Dyson et al., 2003; Petts, 2009; Arthington, 2012). Traditional focus was upon definition of a minimum flow to be released by hydroelectric power plants (Dyson et al., 2003). Wider research has shown that a focus on minimum flows is insufficient and that the required flow should mimic as far as possible the natural flow regime, notably through the incorporation of flow variability (Poff et al., 1997). Poff et al. (1997) argue that incorporating variability into flow requirements should include consideration of flow magnitude, frequency, duration, timing, and rate of change, and this is reflected in methods and tools that take now into consideration a broader range of flow conditions (e.g. Caissie \& El-Jabi, 2003; Arthington et al., 2006).

Hydroelectric power (hydropower) represents a particular challenge for specifying e-flows because electricity generation potential generally scales linearly with the volume of water abstracted and production scales linearly with the volume of water released. Downstream of water intakes or dams, streams may lose some or all of their natural variability, even if they are subject to a minimum flow requirement. Downstream of electricity generation stations, water may be returned to the river, leading to multiple daily flow peaks ("hydropeaks"; Bratrich et al., 2004) that follow consumer demand for electricity rather than natural flow variability. The stress created by hydropower-induced low flows and hydropeaking has been shown to have major impacts upon stream ecosystems (e.g. Brooker \& Hemsworth, 1978; Cushman, 1985; Moog, 1993; Lauters et al., 1996; Céréghino \& Lavandier, 1998; Smokorowski et al., 2011; Schmutz et al., 2015; Schülting et al., 2016, 2019).

In Alpine hydropower systems, there is a third type of impact associated with flow intakes (Gabbud \& Lane, 2016). Traditionally, hydropower is thought to lead to sediment starvation downstream of dams, and associated problems of erosion and bed armouring (Petts \& Gurnell, 2005). However, intakes are different. At intakes, water is abstracted and stored at altitude either to maintain its hydraulic head or for transfer to adjacent valleys for storage behind dams, so increasing their power generation potential. Such intakes seek to separate water and coarser sediment (typically sand and coarser), the sediment accumulating in a settling basin until sediment storage capacity is reached and the basin must be flushed. In some Alpine environments, such as in Switzerland, the area of basins subject to water intake impacts is greater than dams (Margot et al., 1992). Depending on their capacity, in high altitude systems associated with glaciated basins, flushing may be more than daily in frequency during peak glacier melt (e.g. Gabbud et al., 2019). The result is "hydropeaking" but this is not driven by electricity demand, rather by sediment accumulation in intakes, and their capacity to store sediment.

Flushing has two fundamental differences compared with conventional hydropeaking: (a) the release involves a very rapid rise and fall in discharge as the peaks are designed to flush out sediment; the result is a short duration flow events (typically less than one hour in duration); and (2) the water that is flushed contains exceptionally high sediment loads (Gurnell, 1983; Gurnell \& Warburton, 1990) that is transferred through the intakes that maintain sediment delivery downstream, unlike impoundments which interrupt sediment delivery. Both of these changes may impact negatively on the habitat available to 
macrozoobenthos. It is well-established that different macrozoobenthos families, genus and species have different hydraulic preferences, commonly expressed as a shear stress (e.g. Möbes-Hansen \& Waringer, 1998; Mérigoux \& Dolédec, 2004; Dolédec et al., 2007; Mérigoux et al., 2009). As discharge rises, the spatial distribution of shear stress will change and the sites of suitable habitat will shift laterally. This relationship will depend on stream bed bathymetry; for example, in a braided river where changes in discharge are accommodated primarily by changes in width, suitable habitat (in terms of shear stress) in the primary channel at low flows will move into secondary channels at high flows. Implicitly, then, braided rivers should be resilient to flow changes provided macrozoobenthos can migrate laterally. If the discharge rise (or fall) is too great then required migration rates may be too high, and the implicit resilience cannot be realised.

High sediment loads, mobilized through shear stress increases during flushes, may also negatively impact available habitat. Data from hydropower impacted streams suggest almost continual reworking of the primary channel bed due to flushing (Lane et al., 2014; Bakker et al., 2019). Both erosion and deposition may lead to a reduction in the organic matter on the stream bed needed to sustain macrozoobenthos, due to either scour or burial (Orr et al., 2008; Müller et al., 2009; Fuller et al., 2011; Cullis et al., 2014). Scour can lead to direct wash out of organisms whilst burial can make emergence difficult (Wood et al., 2005; Conroy et al., 2018).

The sensitivity to these two sets of processes may be particularly great as water intakes are commonly at higher altitudes (typically at altitudes higher than dams to facilitate water transfer). Flushing tends to take place in systems that may be more environmentally marginal (e.g. colder, Milner \& Petts, 1994; or more turbid, Milner et al., 2001) and hence more sensitive to perturbation. Recently, Gabbud et al. (2019) found a clear correlation between flushing event frequency and macroinvertebrate community abundance and diversity in an Alpine stream subject to flow abstraction and flushing. Whilst the stream had exceptionally low abundance and diversity of macroinvertebrates during the high frequency flushing period in summer, populations rapidly recovered as soon as the frequency decreased in early autumn. Rapid recovery was attributed to the ability of the main stream to recruit individuals from lateral streams. The result was more diversified and more abundant communities in winter and early spring, aided by the fact that the freezing of flow at the stream bed is prevented by krenal water supply. Diversity and population size both fell rapidly when the flushing of sediment accumulated in intakes recommenced in late spring and early summer.

An apparent sensitivity to flushing would follow from the two broad flushing impacts, rapid habitat displacement and rates of geomorphic change, identified above. However, this raises a challenge of attribution. A glacially-fed stream without hydropower impacts would have a natural variability in both discharge and sediment load at the sub-daily scale, variability that may also lead to habitat displacement and channel instability (Gurnell et al., 1999). Burgherr and Ward (2001) and Füreder et al. (2001) found that macroinvertebrate densities were higher in late spring and early autumn than they were in summer, and they attributed this to periods of less frequent stream bed perturbation, low rates of sediment transport, low turbidity, low bed shear stress, as well as the consequences of these for organic matter production and accumulation. Indeed, some species are well-adapted to winter conditions (e. g. Robinson et al., 2001; Brown et al., 2015). Thus, whilst contradicting conventional assumptions (OFEV, 2010), it is quite possible that the observation that winter has more diverse and abundant communities in glacially-fed streams is related to natural flow, sediment load and stream bed perturbation processes rather than hydropower impacts. 
Given this question of attribution, the aims of this paper are two-fold. The first is to assess the extent to which the more diversified and abundant communities in winter and early spring, as compared with summer (Gabbud et al., 2019) can be attributed to what might be expected naturally in a morphologically dynamic Alpine stream as opposed to one impacted by flushing of sediment from intakes. Such evaluation is crucial as the percentage of basins impacted by sediment flushing in Alpine environments can be significant. The second is to use the results from this approach to reflect upon the changes in environmental flow frameworks needed in streams draining glaciated basins where the water that an environmental flow might deliver is typically glacier derived and so cold with high suspended sediment concentration. The design of optimal hydropower management systems to improve the ecosystems associated with such streams remains largely overlooked in management terms.

To address this aim, we revisit the Borgne d'Arolla (Gabbud et al., 2019) and focus upon a braided reach of Alpine stream downstream of glaciated basins with flow intakes, representative of many environments subject to an intake flushing regime. We combine field measurements with habitat modelling for macroinvertebrates to identify how intake flushing impacts instream habitat variation in space and time as compared to what would be expected under naturally varying flow and sediment transport conditions. The results are then used to test the following hypotheses: (1) that habitat suitable for macrozoobenthos potentially exists at all possible flows in the studied stream; (2) that whilst intake flushing produces increases in total habitat availability (as more floodplain is inundated) the sites of suitable habitat are displaced laterally more rapidly than in a natural stream; and (3) that this combines with significant geomorphic impacts (scour and burial) of suitable habitat.

\section{Methods}

\subsection{Study site}

This study was conducted in a $635 \mathrm{~m}$ long braided reach of the Borgne d'Arolla in the southwest Swiss Alps based on data acquired and modelled for the period $7^{\text {th }}$ to the $15^{\text {th }}$ August 2016. This stream is defined by a glacial regime and is fed by a series of both kryal and nival tributaries. The Borgne d'Arolla originates from a number of glaciated tributaries which feed two major intakes, the Bertol Inférieur (or Lower Bertol) and the Tsijiore Nouve (Bakker et al., 2018), $5 \mathrm{~km}$ and $3.5 \mathrm{~km}$ upstream of the study reach; and one which is much smaller, the Pièce intake (Figure 1). Initial data collection (2014 and 2015) using a continuous record of stream temperature suggested that during the summer, daily water temperatures in the study reach were in the range of $5^{\circ}$ to $10^{\circ} \mathrm{C}$, and hence the chosen site is sufficiently far downstream from the glacier for water temperature not to be a limit on macroinvertebrate development (Milner \& Petts, 1994; Milner et al., 2001).

This paper focuses on a braided reach next to the village of Satarma, at an altitude of 1'850 $\mathrm{m}$ above sea level, which comprises an alluvial plain with a mixed gravel-sand, multi-thread stream (Figure 1). The upstream and downstream ends of the reach are bound by bridges that locally canalise the stream. The reach slope is relatively uniform at $0.035 \pm 0.004$ and the mean grain size is $0.05 \pm 0.02 \mathrm{~m}$ (Bakker et al., 2018). The mean wetted width at summer baseflow is $7.7 \pm 2.5 \mathrm{~m}$; during a flushing event, this rises to $28.4 \pm 11.7 \mathrm{~m}$. The reach lies just below the tree-line and so at the Montane-Alpine interface. There are isolated trees within the floodplain, although many of these are dying as a result of sediment-related perturbation. 
The reach has been aggrading and steepening since hydropower exploitation began in the $1960 \mathrm{~s}$, and notably since the 1990s, with mean bed elevations rising over this period by $2 \mathrm{~m}$ at the upstream end of the reach and $1 \mathrm{~m}$ at the downstream end (Bakker et al., 2018). This bed level rise reflects the operation of hydropower intakes upstream. At each intake (circles on Figure 1), there is a small volume (100 to $200 \mathrm{~m}^{3}$ ) settling basin designed to trap gravel and coarser sediment. Then, water passes underground to a second settling basin beneath the intake which can trap up to $10 \mathrm{~m}^{3}$ of sand (Bezinge et al., 1989). The water, which now only contains washload, passes through tunnels to an adjacent valley where it is stored behind a large dam (see Bakker et al., 2018 for more details). Currently, all water is abstracted and there is no minimum residual flow requirement. The gravel and sand settling basins have finite capacity and so have to be flushed when full. This is flushed by temporarily halting the transfer of water to the reservoir, and using the flow instead to wash the sediment out of either the gravel basin or the sand basin and into the main stream. This maintains sediment connection and the associated flushing of the intakes produces enough water to move the majority of flushed sediment downstream through the system (Bakker et al., 2018). As is common in the presence of aggradation, the stream bed does not armour.

Between the intakes and the reach there are a number of unglaciated and unregulated tributaries that join the stream and these, along with some groundwater (i.e. krenal) supply, are sufficient to maintain a baseflow of between 0.5 and $0.8 \mathrm{~m}^{3} \mathrm{~s}^{-1}$ at the study reach with negligible turbidity. When the intake is flushed, the discharge rises rapidly in the Satarma reach, between 40 minutes (typical of Tsijiore Nouve, Figure 1) and 55 minutes (typical of Bertol Inférieur) after flushing begins. There is relatively little attenuation between the intakes and Satarma.

\subsection{Turbidity and discharge measurements}

A pressure transducer with a built-in temperature sensor (Campbell Scientific CS451 (USA), water level resolution $0.0035 \% \mathrm{FS}$; temperature precision $\pm 0.2^{\circ} \mathrm{C}$ ) and infrared-based downward looking turbidity probes (Campbell OBS-3+ (USA); NTU precision 0.5 NTUs) were installed in the canalised section at the upstream and downstream end of the study reach (Figure 1). The turbidity probes were installed with a low and high signal range ranging up to 1000 and 4000 NTUs respectively. Data were logged to a river bank mounted Campbell Scientific data logger (CR200X, USA). The loggers were programmed to take 10 measurements with 2 second intervals each minute. The mean and standard deviation were registered every 10 minutes under normal flow conditions (low concentration; < 50 NTUs) and each minute during a flushing (high concentration; $\geq 50$ NTUs) event.

We chose to use the downstream data as the data from upstream probes were sensitive to local scour and fill of the stream bed. Determining an accurate stage-discharge rating curve at this site is difficult because of frequent changes in the river bed cross section. However, all of the upstream intakes have built in broad-crested weirs. These measure discharge to a high precision (c. $\left.0.1 \mathrm{~m}^{3} \mathrm{~s}^{1}\right)$ for regulatory reasons. We use data from them to calibrate the stage record. During flushing, the flow intake discharge drops rapidly to zero, rising back to previous values as soon as flow abstraction recommences. As the natural rates of change of discharge in these systems are relatively slow, except during storm events, it is possible to interpolate the discharge that would have been abstracted if flushing had not occurred, and hence the total volume of water flushed downstream (e.g. Gabbud \& Lane, 2016; Bakker et al., 2018).

As a first step, we identified those flushes, 11 in total during the study period, where discharge interpolation was straightforward (i.e. flushes within a period of steadily rising or 
falling discharge) and where there was no impact on the events from the opening of intakes further upstream. For each such flush, $j$, we calculated the volume of water released $\left(V_{j}\right)$. We then calculated an index $(I)$ above baseflow stage $\left(S_{b}\right)$ from the stage data at our measurement sites up and downstream of the investigated reach:

$$
I_{j}=\sum_{i=1}^{n}\left(S_{i}-S_{b}\right)^{1.67}
$$

where : $S_{i}=$ stage at time $i$; and $n=$ number of minutes where the stage was impacted by the flush. As this was for a canalised section, with near vertical side walls, and as all flows remained within bank, we would expect water level to increase at approximately the power 1.67. We then regressed $V_{j}$ on $I_{j}$ to produce the following relationship:

$$
V_{j}=6191.1 I_{j}+435.0
$$

with an $\mathrm{R}^{2}$ of $88.7 \%$. We then applied this to each $S_{i}$ record in the series by replacing $I_{j}$ with $S_{j}$, to give an estimate of the volume of water passing through the reach per minute, from which we could calculate a discharge $\left(\mathrm{m}^{3} \mathrm{~s}^{-1}\right)$. As this method explicitly uses the form of the hydrograph measured at the station to distribute the water due to the flush, it deals with attenuation between each intake and the station.

This method does not include the baseflow below the level of the gauge height $S_{b}$ and which will be constant provided the gauge remains submerged, which was the case throughout the study period. As noted above, the bathymetric data collection focused on a period of lowest flow and this was coincident with the gauge being only just submerged. Thus, to estimate the low flow we used the inundated extent to calibrate the 2D hydraulic model described below, including both baseflow discharge and roughness as model calibration parameters. This gave us an estimated baseflow of $0.55 \mathrm{~m}^{3} \mathrm{~s}^{-1}$, which we added to all flows estimated using [2].

Finally, as we wanted to compare the habitat associated with the natural flow regime and with the abstraction and flushing regime, we took the natural flows at the intakes and combined these with the $0.55 \mathrm{~m}^{3} \mathrm{~s}^{-1}$ baseflow, but delayed by the travel time that the difference between the flushing time and the stage record suggested. Thus, the natural flow regime is not corrected fully for attenuation effects between the intakes and the study reach. This is a limit to the comparison we make, but we note that: (1) the flow minima under natural conditions would have always been greater than $1.4 \mathrm{~m}^{3} \mathrm{~s}^{-1}$, with the associated flow depth reducing attenuation, as compared with a flush release to the lower baseflow of $0.55 \mathrm{~m}^{3} \mathrm{~s}^{-1}$; and (2) the failure to represent attenuation is likely to make the natural flow regime more severe than it would otherwise have been (with additional attenuation effects).

\subsection{Turbidity and organic matter availability}

Temperature and turbidity themselves may have direct impacts upon the harshness of Alpine streams for macroinvertebrates. They may also be important for organic matter availability, particularly turbidity, and hence macroinvertebrate food sources. In practice, turbidity can have two different effects (Uehlinger et al., 1998). First, turbidity should reduce the amount of photosynthetically active radiation (PAR) that reaches the stream bed causing reduced primary production on the beds of glacially-fed streams during periods when kryal sources 
are dominant over other sources (Uehlinger et al., 1998; Füreder, 1999; Burgherr \& Ward, 2001; Füreder, 2007). Second, as the increase in turbidity in glacially fed streams is associated with increased suspended sediment concentrations, and these are commonly abrasive, turbidity could also lead to greater scour of benthic algae, such as periphyton, on the stream bed. We address this process below.

To calibrate the turbidity probes described above, we obtained thirteen water samples for the determination of suspended sediment concentration. The samples had concentrations ranging from 170 to $1200 \mathrm{mgl}^{-1}$. The calibration relationship between turbidity and suspended sediment concentration was weakly non-linear (best represented by an exponential) in the range of concentrations considered here, reflected the expected response of this probe, and had an $\mathrm{R}^{2}$ of $97.6 \%$. The focus of the interpretation is on turbidity because of its control on PAR, but we report suspended sediment concentrations to help compare our results with others in the literature.

Relatively small increases in turbidity have been shown to result in quite major reductions in PAR in glacially-influenced water bodies (Lloyd et al., 1987; Uehlinger et al., 1998; Rose et al., 2014). To interpret the effects of hydropower management upon PAR we develop a simple index of possible light attenuation due to glacially-derived suspended sediment load. Research has shown (e.g. Modenutti et al., 2000; Rae et al., 2001; Rose et al., 2014) that glacially-derived suspended sediment load can have a significant influence on light attenuation but that this is commonly dependent upon catchment characteristics (e.g. geology) which influence the nature of the suspended sediment produced. In the absence of detailed data on turbidity impacts on light attenuation, we chose a relatively simple index to gauge how measured turbidity values $(T)$ might interact with flow variability to determine the spatial extent of the euphotic zone, where the PAR at the stream bed $\left(I_{d}\right)$ is at least $1 \%$ of the incoming PAR, $I_{o}$ (Kirk, 1994). Following Lloyd et al. (1987) we apply

$$
I_{d}=I_{o} e^{-K d}
$$

where $d$ is depth. Given the lack of data needed for more physically based approaches (e.g. Gallegos, 2001) we use empirical relationships for the attenuation coefficient $K$ obtained for glacially-fed lakes in Alaska, Canada and New Zealand:

$$
\begin{aligned}
& K=0.064 T-0.093 \text { (Lloyd et al., 1987) } \\
& K=0.041 T+0.448 \text { (Rose et al., 2014) } \\
& K=0.037 T+0.093 \text { (Rose et al., 2014) }
\end{aligned}
$$

The relationships [3] and [4] allow us to convert the measured turbidity time-series into a corresponding euphotic depth $\left(d_{e}\right.$, i.e. when $\left.\mathrm{I}_{d} / \mathrm{I}_{\mathrm{o}}=0.01\right)$. By convolving this with the distribution of inundated hydraulically-modelled depths for the study reach (see below) and the time-series of discharge at Satarma, we could determine time-series of the inundated area of the stream and the percentage with water depths lower than the euphotic depth.

\subsection{Stream and floodplain bathymetry and 2D hydrodynamic modelling}

The 2D hydrodynamic modelling was performed with the BASEMENT v2.7 hydraulic model developed by the ETHZ (ETHZ, VAW, 2017). The model solves the depth-average form of the Navier-Stokes approximation of the system of differential equations for mass 
and motion conservation on a finite element mesh (Vetsch et al., 2017). Reynolds decomposition with a zero order eddy viscosity turbulence model was used to represent the effects of turbulence. A Manning type friction relationship was used with a quadratic friction law to determine the bottom shear stresses. Model solution used an exact Riemann solver. Time steps were set automatically to satisfy the Courant-Friedrichs-Lewy condition. The downstream boundary used a depth-discharge relationship based upon the Manning equation. This boundary was set downstream of the zone of interest in this study such that the boundary condition had no impact upon the model results used in subsequent analyses. In all model runs a steady discharge was applied at the upstream section and the model run to steady state, with the mass balance error (the difference between mass inflow rate and mass outflow rate) less than $0.5 \%$.

The model relies upon bathymetric data to establish the finite element mesh. A Digital Elevation Model (DEM) of the area was constructed by UAV imagery with the photogrammetric software Pix4Dmapper v. $3.3^{1}$ from images taken with a SenseFly ebee (plane) drone. Images were obtained on the $12^{\text {th }}$ of August 2016 using two flying heights and at an angle of $7^{\circ}$, with a superposition of images of at least $70 \%$, to reduce the effects of distortion (doming effects) (Carbonneau \& Dietrich, 2017). The georeferenced DEM resolution was $0.03 \mathrm{~m}$. A bathymetric correction was applied to the DEM to correct for the effects of refraction using Carbonneau \& Dietrich (2017), developed for SfM following the work of Westaway et al. $(2000,2001)$. The DEM of the channel bathymetry was resampled at $0.5 \mathrm{~m}$ resolution in ArcGIS $^{2}$ for the hydraulic modelling, a resolution that reflected a compromise between representation of topographic detail and computational efficiency. This DEM was then converted into an unstructured triangular mesh through the BASEmesh module included in the open source geographic information system software Quantum GIS ${ }^{3}$. The computational mesh of triangular elements was the basic grid used for the simulations (Vetsch et al., 2017). Bathymetric data were also acquired on the $26^{\text {th }}$ of July 2016 and this allowed us to have a wider sense of the extent to which the floodplain is reworked under the current flow regime.

Initial testing of model parameters suggested that turbulent viscosity and friction slope at the downstream end of the simulation were much less important influences upon model predictions than Manning's $n$. Thus, to calibrate the model, focus was placed upon Manning's $n$ and discharge, treating baseflow discharge as unknown given the measured stage from the pressure transducer described above. We included $n$ as a calibration parameter (constant value) as $n$ is likely to be an effective parameter in this case (that is the values needed to optimise the model may be different to those measured from grain-size, because other processes are being represented in the model; see Lane, 2014). We applied uniform values of Manning's $n$, given evidence from Bakker et al. (2019), from 0.04 to 0.08. After some initial simulations, we estimated baseflow to be optimised (against inundation extent and depth, see below) between 0.50 and $0.60 \mathrm{~m}^{3} \mathrm{~s}^{-1}$ regardless of Manning's $n$ used, and so we undertook preliminary simulations with $0.50,0.55$ and $0.60 \mathrm{~m}^{3} \mathrm{~s}^{-1}$.

The bathymetry optimization process allows us to assess spatial patterns of inundation as one output of the correction is a map of inundation extent. As this is a multi-thread reach, small changes in water level, whether due to roughness or discharge, tend to lead to large changes in inundation extent so making inundation extent ideal for model calibration (see also Smith, 1997; Simeonov et al., 2013; Williams et al., 2013; Pan et al., 2016; Garambois

\footnotetext{
${ }^{1}$ See http://www.pix4d.com/ for further information

${ }^{2}$ See http://www.arcgis.com/index.html for further information

${ }^{3}$ See http://www.qgis.org/en/site/ for further information
} 
et al., 2017; Benjankar et al., 2018). Thus, model predictions of inundation extent were compared with the spatial patterns of inundation from the orthoimage using a Kappa $(\kappa)$ statistic (after Cohen, 1960) and a Reduced Major Axis (RMA) regression analysis. Kappa was defined by

$$
\kappa=\frac{n \sum_{i=1}^{2} n_{i i}-\sum_{i=1}^{2} n_{i+} n_{+i}}{n^{2}-\sum_{i=1}^{2} n_{i+} n_{+i}}
$$

where $n$ is the total number of cells, $i=1$ indicates wet, $i=2$ indicates dry and + indicates summation along columns $(+i)$ or rows $(i+)$. This parameter allows us to objectively quantify the correspondence between inundation predictions and observations corrected for the effects of random agreement between them. The bathymetric correction also provided distributed information on water surface elevation and hence flow depth, allowing us to compare predicted and observed flow depths. RMA regression was chosen because of the possibility of error in both depth predictions and depth observations. Observed depths were in error because of the resolution of the model $(0.50 \mathrm{~m})$ as compared with grain size, assumptions made in the water surface interpolation (e.g. a locally horizontal water surface) used in the bathymetric correction and errors in identifying the water edge needed for the interpolation. We quantified both the slope of the regression $(m)$, as an indicator of either over- or under-prediction and also the scatter around the regression, using correlation $(r)$. All three parameters (kappa, $m$ and $r$ ) are optimised at values of 1 . Table 1 summarises the main and best interpolation results. We adopted a baseflow discharge of $0.55 \mathrm{~m}^{3} \mathrm{~s}^{-1}$ and a Manning's $n$ value of 0.06 .

Once the model was optimized, discharges were simulated every $0.05 \mathrm{~m}^{3} \mathrm{~s}^{-1}$ from $0.10 \mathrm{~m}^{3} \mathrm{~s}^{-1}$ to $1 \mathrm{~m}^{3} \mathrm{~s}^{-1}$ and every $0.25 \mathrm{~m}^{3} \mathrm{~s}^{-1}$ to $9 \mathrm{~m}^{3} \mathrm{~s}^{-1}$, leaving all other parameter values constant. This discharge range reflected the estimated discharge record for the study period. Each discharge was checked for mass conservation (loss less than $0.5 \%$ ) and used to extract water depth and northing and easting velocity components per discharge.

\subsection{Hydraulic determination of habitat availability}

In order to quantify how available habitat by hydroelectric power related water management, a fuzzy habitat model was used (after Lane et al., 2006). The underlying philosophy of the modelling is the principle that stream hydraulics provides a critical linkage between human impacts on stream conditions and the availability of habitat which, if habitat is limiting, may translate into a biological response (Dunbar et al., 2011). In this paper, the focus is upon the microhabitat available at the reach scale and how this is impacted by hydroelectric power activities. Thus, it draws directly upon the notion of microhabitat habitat suitability models or indices (e.g. Bovee, 1986; Gore et al., 2001; Vadas \& Orth, 2001; Lane et al., 2006; Dunbar et al., 2011), in which suitability is classed, based upon empirically determined organism preferences for certain combinations of hydraulic parameters. Such models have now proved to be a valuable tool for assessing environmental flows (e.g. Ahmadi-Nedushan et al., 2006, 2008; Garcia et al., 2011; Poff et al., 2017; Benjankar et al., 2018) especially when coupled with two-dimensional models (Benjankar et al., 2015), because they allow simulation of how the distribution of suitable habitat changes in space, as a function of discharge. This may be particularly important in Alpine streams with relatively complex bathymetry as suitable habitat may become available at higher (or lower) discharges in other zones of the stream-floodplain system. 
In this paper we adopt an approach based upon fuzzy logic (e.g. Jorde et al., 2000; Adriaenssens et al., 2006; Van Broekhoven et al., 2006; Tonina \& Jorde, 2013), which reflects the observation that the boundary between habitat classes will rarely be abrupt (Mouton et al., 2013) but gradual as a consequence of both producer and user uncertainty (Ahmadi-Nedushan et al., 2008); producer uncertainty in terms of classing hydraulic variables as habitat because the hydraulic variables may be in error; and user uncertainty because ecological boundaries (such as between classes) may be gradual and variable in time and space (Strayer et al., 2003), as well as compensatory and interacting, e.g. where less than optimal velocity is compensated for by more than optimal depth (Jorde et al., 2001). Although used less widely than for fish, fuzzy modelling has been used for estimated instream habitat availability for macroinvertebrates (e.g. Adriaenssens et al., 2006; Van Broekhoven et al., 2006, 2007; Mouton et al., 2009; Schneider et al., 2017; Theodoropoulos et al., 2018).

In our approach, we focus upon bed shear stress. Bed shear stress has proved to be valuable as an indicator of habitat availability because increases in shear stress can lead to densityindependent loss of benthic macroinvertebrates (Lancaster and Hildrew, 1993) with a shear stress - loss relationship that depends on at least the family, sometimes the genus and even individual species and sub-species (e.g. Möbes-Hansen \& Waringer, 1998; Mérigoux \& Dolédec, 2004; Dolédec et al., 2007; Mérigoux et al., 2009). Relationships between invertebrate abundance and shear stress appears to be stronger than relationships between abundance and other hydraulic parameters (e.g. velocity, as used by Gore et al., 2001) and so we use shear stress in this paper.

Most studies of the preferences of macroinvertebrate families for particular shear stresses make no distinction between the effects of shear stress change on the ability of an organism to remain in a particular part of a stream, which we now label its habitability $(Y)$ and the effects of shear stress upon erosion and deposition processes. Erosion may lead to enforced drift for macroinvertebrates even if the hydraulic definitions defined by velocity and flow depth are acceptable. Scour may lead to loss of organic matter and hence food sources. At present, this is a subject of significant uncertainty. Studies have suggested net loss of primary production due to high discharge events in Alpine and polar ecosystems (e.g. Müller et al., 2009; Cullis et al., 2014). However, there appear to be few generalizable relationships (e.g. excess Shield stress values that might indicate organic matter loss) not least because: different communities appear to be more or less resistant to erosion (Biggs \& Thomsen, 1995; Müller et al., 2009); scour of organic matter depends on whether or not communities are actively growing (Biggs \& Close, 1989); and local geomorphic conditions may determine sensitivity of organic matter scour to extreme flow events (Fuller et al., 2011). In addition, this process appears to be relatively understudied in Alpine environments (Gooseff et al., 2016).

For this reason, we take the basic assumption that organic matter loss is likely to correlate with the probability of bed movement, and hence we need to focus on the probability of scour. The question of burial is equally important. Evidence suggests that whilst the sensitivity of individual taxa to burial is variable (Wood et al., 2005), burial depth can lead to slower emergence, as can burial by finer sediment (Conroy et al., 2018). Burial may also reduce access at the stream bed surface to organic matter (Orr et al. 2008).

Given the above, we assume that both too much erosion (scour) or too much deposition (burial) could be detrimental to macroinvertebrates. It is also probable that some scour, notably of fines, may support macroinvertebrate life, especially given the very high silt and sand loads in this kind of stream. An organism that has a preference $(Y)$ for very low shear 
stresses, for example, may be at risk of substantial sediment deposition at those shear stresses, such that what is optimal for the organism is shifted towards higher shear stresses. One that has a preference for high stresses may be at risk if those stresses also lead to scour (of sediment or potential food sources such as organic matter) in the particular stream setting under consideration. Thus, we introduce a second classification of shear stress which we call geomorphic $(G)$ and which reflects the exposure of sites to the risk of severe scour or deposition. Both $Y$ and $G$ are explained below, as is the way we combine them in a fuzzy habitat model.

\subsection{Estimation of habitability preferences $(Y)$}

Dolédec et al. (2007) compiled relationships between density and FliesswasserStammTisch (FST) hemisphere estimates of shear stress for small European streams, with data presented to family, genus and sometimes species level. We used data from Gabbud et al. (2019) to identify the dominant families present in the main stem of the study stream during the samples of May 2016 and May 2017. We chose May because at the altitudes of the streams used in this study, conditions should be suitable for macroinvertebrate life and flushing has not yet begun. Four families comprised $80 \%$ of the density of macroinvertebrates measured in the stream in 2016; Chironomidae (58\%); Leuctridae (18\%); Limnephilidae (0.4\%); and Baetidae (4\%); and $84 \%$ in 2017; Chironomidae (21\%); Leuctridae (48\%); Limnephilidae (8\%); and Baetidae (7\%). The difference between May 2016 and May 2017 can be attributed to a more clement winter in 2017 which meant that suitable conditions (i.e. temperature) for the Tricoptera Limnephilidae probably occurred slightly earlier in the year. We used Dolédec et al. (2007) to identify the normalised $\ln$ (abundance) of shear stress for each of these four families. Their normalisation was such that the $\ln$ (abundance) summed across all measured shear stresses was 1 . Dolédec et al. (2007) do provide data to a finer taxonomic resolution but using finer data risked identifying habitat requirements that were too specific (i.e. locally adapted) to the sites used in their study. Each normalised $\log$ (abundance) was classified on the same scale into poor with log abundance of 0.033 or less, medium as 0.033 to 0.067 , and good as 0.067 to 1.0 . The associated FST shear stress estimates were converted into shear stresses using data in Statzner \& Müller (1989). It should be noted that there is an equivalence between the bottom shear stress measured using FST hemispheres and the bottom stresses modelled in a depth-averaged solution of the Navier-Stokes equations as used here: although such a model predicts the depth-averaged velocity, in the depthaveraged momentum equations, it is the bottom stress that is used and it is this that is predicted by the model. The bottom shear stress $\left(\tau_{b}\right)$ is calculated from the quadratic friction law used by the hydraulic model BASEMENT using

$$
\tau_{b}=\rho g \frac{n^{2}}{d^{1 / 3}} v^{2}
$$

\subsection{Geomorphic preferences $(G)$}

The second element of the habitat availability we wished to quantify was a measure if the risk of burial/scour within the stream. In theory, this is a function of both local hydraulics and upstream sediment supply. We assume in this stream that the latter is not a limit given high rates of sediment transfer (Bakker et al., 2019). We quantify the critical Shields stress corrected for local bed slope:

$$
\tau_{o c}=0.06\left(\rho_{s}-\rho_{w}\right) g D_{50}
$$


We assume that the bed has little armouring due to high sediment loads and frequent disturbance, which matches visual observations in the field. Erosion of the median grain sizes should occur when $\tau_{b}>\tau_{o c}$. We are using a single sediment size fraction. Thus as $\tau_{b}$ rises towards $\tau_{o c}$, progressively coarser material should be transported. With continual increases of $\tau_{b}$ above $\tau_{o c}$ there is a growing likelihood of complete bed break up and scour to great depths. This provides a means of parameterising $G$.

In relation to burial, we assume that once $\tau_{o c}$ falls below the threshold for transport of coarse sand, the risk of deposition increases and the location is likely to be poor. This broadly corresponds to what Conroy et al. (2018) observed as the threshold when time for body emergence from a deposit increase markedly, although this does depend on burial depth. For values of $\tau_{o c}$ equivalent to the range coarse sand through to fine gravel, the shear stress is medium and for fine gravel through coarse gravel the shear stress is good. The coarse gravel threshold is important because coarser grain sizes are likely to act as anchoring refugia and if these sizes begin to move, then there is a growing probability of such refugia being lost. If cobbles (or greater) can move then we assume that the site is poor as the scour depths implied are greater than $0.064 \mathrm{~m}(\mathrm{OFEV}, 2010)$, given the observed role of cobbles as refugia (Hose et al., 2007).

To aid interpretation, we calculate the percentage of the bed inundated at low flow $(Q=0.55$ $\mathrm{m}^{3} \mathrm{~s}^{-1}$ ) that becomes mobile through time according to [6] and [7]. With these relationships, $0.14 \%$ of the bed is mobile at baseflow, which also matches our observations of negligible sediment movement between flushes.

\subsection{Fuzzy habitat model}

Fuzzy subsets were defined for habitability $\left(Y_{i}\right)$ and geomorphology $\left(G_{i}\right)$ for each shear stress predicted by the hydraulic model simulations:

$$
\begin{aligned}
Y_{p} & =\left\{\left[\tau_{o}, \mu_{Y_{p}}\left(\tau_{o}\right)\right] ; \tau_{o} \in Y, \mu_{Y_{p}}\left(\tau_{o}\right) \in[0,1]\right\} \\
Y_{m} & =\left\{\left[\tau_{o}, \mu_{Y_{m}}\left(\tau_{o}\right)\right] ; \tau_{o} \in Y, \mu_{Y_{m}}\left(\tau_{o}\right) \in[0,1]\right\} \\
Y_{g} & =\left\{\left[\tau_{o}, \mu_{Y_{g}}\left(\tau_{o}\right)\right] ; \tau_{o} \in Y, \mu_{Y_{g}}\left(\tau_{o}\right) \in[0,1]\right\} \\
G_{p} & =\left\{\left[\tau_{o}, \mu_{G_{p}}\left(\tau_{o}\right)\right] ; \tau_{o} \in G, \mu_{G_{p}}\left(\tau_{o}\right) \in[0,1]\right\} \\
G_{m} & =\left\{\left[\tau_{o}, \mu_{G_{m}}\left(\tau_{o}\right)\right] ; \tau_{o} \in G, \mu_{G_{m}}\left(\tau_{o}\right) \in[0,1]\right\} \\
G_{g} & =\left\{\left[\tau_{o}, \mu_{G_{g}}\left(\tau_{o}\right)\right] ; \tau_{o} \in G, \mu_{G_{g}}\left(\tau_{o}\right) \in[0,1]\right\}
\end{aligned}
$$

where $p=$ poor; $m=$ medium and $g=\operatorname{good} ; \mu_{L i}(l)$ is the grade of membership of the predicted value $l$ (i.e. $\tau_{o}$ ) in $L_{i}$ (i.e. $Y_{i}$ or $G_{i}$ ). If $0<\mu_{L i}(l)<1$, membership of $L_{i}$ is partial and the prediction (of $\tau_{o}$ ) is a member of more than one $Y_{i}$ or $G_{i}$. We then specify a fuzzy rule for Habitat $\left(H_{k}\right)$ where

$$
\text { If } Y_{i} \otimes G_{i} \text { then } H_{k} \text {, for } K \text { values of } k
$$

where $K$ is the number of habitat classes. We use a product operation rule (Wang, 1994) to define the degree of fulfilment of a particular $H_{k}$ : 
As $\mathrm{i}=3$, [7] gives 9 rules and hence $K$, the number of habitat classes, is 9 . We reduce these 9 classes using a symmetrical habitat classification that weights $Y_{i}$ and $G_{i}$ equally (Table 2). This could be made more sophisticated by changing the weightings to reflect the relative importance of velocity and depth in contributing to a particular habitat class, notably through model calibration (e.g. Theodoropoulos et al., 2018). However, as this stream is largely void of life, and we do not know a priori which flow conditions (e.g. baseflows or flushing flows) limit the system, such calibration was not feasible. This is a weakness of our approach in this case. In a final stage, we defuzzify the results to provide a single crisp habitat suitability index (HSI) scaled between 0 and 1 , with 1 corresponding to the situation when both $Y$ and $G$ are singularly classed within the categories $Y_{g}$ and $G_{g}$.

The fuzzy model was applied for each of the four families identified above for each simulated discharge. This allowed visualisation of the spatial distribution of habitat. We produced two reach-scale habitat indices: (1) a measure of total habitat, the sum of all HSI values, which we label absolute habitat availability (AHA); and (2) a measure of habitat quality, equivalent to a weighted usable area (Lamouroux \& Jowett, 2005), taken as the AHA divided by the area that was inundated, which we label weighted habitat availability (WHA) (Lane et al., 2006; Ahmadi-Nedushan et al., 2008). By looking spatially across all simulated HSI values for each simulated discharge, we were able to identify the maximum HSI simulated and the discharge responsible for that HSI, so allowing visualisation of how optimal habitat reorganised itself spatially as discharge changed. Finally, we used the discharge time-series for both the natural flow and the flow with abstraction and flushing to look up corresponding values of AHA and WHA, and so produce time-series of the two.

\subsection{Validation of fuzzy habitat model predictions}

In order to validate the model, we have compared fuzzy habitat model predictions with samples reported in Gabbud et al. (2019). This is not straightforward because the Borgne d'Arolla has negligible life during the flushing period (June through August) and so very little signal to explain. During the winter, it is snow covered. Logistical issues (time) also prevented macroinvertebrate sampling at the same moment as data collection for the hydraulic modelling. However, we attempted a partial validation by pooling the main channel sample results of Gabbud et al. (2019) (sites C1, D1 and D5) for three periods; March (characteristic of winter, when the river is snow-covered); May (characteristic of spring, when the river is snow free but before flushing starts) and June through August (characteristic of the main flushing period). We are able to attribute a characteristic discharge to each of these periods. For the May period, this is the baseflow given that water is being abstracted but because the abstraction is predominantly snow melt, there is no flushing. For June through August, we take the peak discharge characteristic of flushing as this is the flow that is likely to impact macroinvertebrate populations (when scour and burial are at a maximum). For March, we take an estimate of the flow as krenal sourced at about $0.10 \mathrm{~m}^{3} \mathrm{~s}^{-1}$. For each of these flows, we calculate the mean and standard deviation of HSI values in the main channel zone characteristic of where the samples were measured. The results are encouraging (Figure 2). Only two points fall off a linear relationship between log abundance and mean habitat score. Including all data, the correlation is 0.510 (significant at $\mathrm{p}<0.05$ ); excluding the two outliers, the correlation is 0.941 (significant at $\mathrm{p}<0.05$ ). These two outliers are both for the family Baetidae for the March and May comparisons. Whilst there are only three data points (March, May and flushing) for each family, which is a limit of this validation approach, for Leuctridae, Limnephilidae and Chironomidae there is a 
systematic increase in abundance with mean habitat score. The fact that we don't see this for Baetidae may imply that the hydraulic controls (i.e. $Y$ and $G$ ) are not sufficient to explain Baetidae populations in this kind of stream. Whilst this is only a partial validation, and has substantial limits, it confirms that the modelling approach is suitable for answering the questions being posed in this paper.

\section{Results}

Time series of the measured and modelled datasets are provided in Figure 3. Figure 3a shows how the regime with abstraction and flushing leads to relatively long duration periods of low flow, at or below $0.55 \mathrm{~m}^{3} \mathrm{~s}^{-1}$, coupled with periodic high flows when flushes arrive. The baseflows are uniformly lower than would be expected under natural conditions (Figure 3a). Despite attenuation, the flushing flow can be higher than expected under natural conditions because for some night-time flushes, an intake upstream of the Bertol Inférieur intake is opened and its water is added to that of the Bertol Inférieur water. Note that such data points are excluded from the calibration.

The temperature followed a clear diurnal cycle (Figure $3 \mathrm{~b}$ ) and was above $6^{\circ} \mathrm{C}$ and below $10^{\circ} \mathrm{C}$ throughout the investigated period. The flushes typically lead to a drawdown in temperature but this was generally negligible. Aside from a short period in Day 1, the turbidity was extremely low between flushes (Figure 3c), around 50 NTUs. Flushes could lead to extremely rapid increases in turbidity, to as high as 2500 NTUs. From Day 5 onwards, there is a general association between the size of the flush and the maximum turbidity reached. The latter may reflect the fact that the smaller flushes relate to the sand traps which, whilst producing significant sand supply, are of shorter duration and attenuate rapidly downstream (Figure 3a; see also Bakker et al., 2019), producing lower turbidity peaks.

Figure $3 \mathrm{~d}$ shows how the euphotic depth evolves through time. First, flushes increase turbidity to reduce the euphotic depth to values typically less than $0.05 \mathrm{~m}$. Second, the curves also show how sensitive the euphotic depth is to turbidity changes at low turbidity, such as between Days 5 and 6 after major flushing events during Day 4 and at the start of Day 5 (Figure 3c), when turbidity falls rapidly, but euphotic depth recovers more slowly. Third, between flushes, euphotic depth recovers over the timescale of hours to levels that are much greater than water depths typically found in this reach stream. This has the effect of making large areas of the stream bed shallower than the euphotic depth (Figure 3d) between purges, typically $>90 \%$ for long periods of time. Given that the flow abstraction regime takes all kryal sources of water in this basin, what contributions remain are largely krenal (there are negligible nival sources in August) such that between flushes euphotic depths are much deeper than they might have been under natural conditions without flow abstraction. In terms of suspended sediment concentrations, whilst a purge is passing through, mean suspended sediment concentrations were very high with substantial variability $(4,900 \pm 1,195$ $\mathrm{mgl}^{-1}$ ) (beyond the range of calibrated suspended sediment concentrations, hence the high uncertainty). During baseflow, mean concentrations were substantially lower and less variable $\left(378 \pm 11 \mathrm{mgl}^{-1}\right)$.

Figures $3 \mathrm{e}$ and $3 \mathrm{f}$ show two contrasting trends in terms of habitat availability. During flushing, total available habitat tends to increase rapidly (Figure 3e), to a degree that is variable between the four families. In rank order, conditions at all flows are best for Baetidae, followed by Chironomidae, Leuctridae and Limnephilidae. The weighted habitat 
availability declines rapidly during flushing (Figure 3f), but this can reverse at the very highest flushing flows (e.g. on days 8 and 9). This observation suggests the stream morphology is conditioning habitat availability; initial rises in flow degrade available habitat in existing inundated areas at a rate that is greater than the inundation of new areas creates it. This is slowed and reversed at higher flows and we explore this below.

When compared with natural flows (Figures $3 \mathrm{~g}$ and $3 \mathrm{~h}$ ), the abstraction regime reduces absolute habitat availability across all families, but improves weighted habitat availability. This is not surprising if the primary effect of higher flows (whether due to flushing or natural stream flow due to glacier melt with no abstraction) is to increase absolute habitat availability. However, comparing Figures $3 \mathrm{~g}$ and $3 \mathrm{~h}$ with Figures $3 \mathrm{e}$ and $3 \mathrm{f}$ reveals a second and more critical issue. In a natural system, absolute and weighted habitat availability change much more gradually than in a system subject to flushing meaning that very rapid lateral displacement may be needed if an organism is to profit from improving habitat elsewhere within the river-floodplain system. This spatial issue is further considered below.

Figure 3i shows percentage of the stream bed are likely to be active under both the abstraction-flushing and natural regimes. Reflecting the discharge variation, this suggests that abstraction leads to long periods of more stable bed conditions interspersed between very rapid increases in bed instability during flushing events. Levels of bed activity in the low flow inundated channel are much higher for the natural channel case, but as with habitat, levels of bed instability rise and fall more slowly. Figures $3 \mathrm{j}$ and $3 \mathrm{k}$ show the quantity and the percentage inundated area where the water depth is lower than the euphotic depth and light can reach the stream bed.

The data shown in Figures 3e through $3 \mathrm{~h}$ suggest that changing flow leads to spatial reorganisation of the locations where suitable habitat is to be found. Figure 4 illustrates how suitable habitat evolves in space for a range of discharges based upon those shown in Figure $3 \mathrm{a}$, here for the case of Leuctridae. At a flow close to the summer baseflow $\left(0.5 \mathrm{~m}^{3} \mathrm{~s}^{-1}\right)$ the main channel is present as a meandering thread generally with HSI values between 0.1 and 0.15 . However, the conditions in this main channel are marginally better at lower flows (Figure 4, $0.1 \mathrm{~m}^{3} \mathrm{~s}^{-1}$ ). By $1.0 \mathrm{~m}^{3} \mathrm{~s}^{-1}$, the white zones of no suitable habitat in the main channel have widened, more so by $1.5 \mathrm{~m}^{3} \mathrm{~s}^{-1}$. At this discharge there is the start of anabranch opening and this continues to $4.5 \mathrm{~m}^{3} \mathrm{~s}^{-1}$. At this discharge, the main channel evidence at $0.5 \mathrm{~m}^{3} \mathrm{~s}^{-1}$ is entirely white, suggesting no suitable habitat is present. Thus, as discharge rises, zones of more suitable habitat move from the main channel to anabranches and zones initially the most suitable decline in suitability. This is reflected in the spatial displacement of where optimum habitat suitability is to be found as a function of discharge (Figure 5). For all four families (Figure 5), there is a range of discharges within the reach at which optimal habitat is found, and reflecting the braided nature of the river-floodplain system (Figure 1), as discharge rises, habitat suitability in some parts of the stream declines, but new zones become inundated providing suitable habitat. Even at high flows there is potentially suitable habitat available, but where it is to be found moves laterally.

Figure 6 provides plots of changes in absolute and weighted habitat availability as a function of discharge for all four families. The absolute habitat availability rises for all families to between $0.75 \mathrm{~m}^{3} \mathrm{~s}^{-1}$ (Limnephilidae) and $0.90 \mathrm{~m}^{3} \mathrm{~s}^{-1}$ (Baetidae) after which it declines very slightly to between $1.00 \mathrm{~m}^{3} \mathrm{~s}^{-1}$ and $1.25 \mathrm{~m}^{3} \mathrm{~s}^{-1}$ for all families after which it rises to around 5 $\mathrm{m}^{3} \mathrm{~s}^{-1}$ in all cases. This pattern reflects the stream bathymetry as $0.80 \mathrm{~m}^{3} \mathrm{~s}^{-1}$ is approximately the channel capacity of the main channel and when this capacity is reached, there is negligible increase in inundated width as discharge increases, water depth rises, roughness falls, flow velocity rises, and so shear stress rises; and absolutes habitat availability falls. 
This pattern is shown for Leuctridae in Figure 4 by comparing discharges $0.5 \mathrm{~m}^{3} \mathrm{~s}^{-1}$ and 1.0 $\mathrm{m}^{3} \mathrm{~s}^{-1}$. By $1.5 \mathrm{~m}^{3} \mathrm{~s}^{-1}$, the flow is sufficient to occupy anabranches and absolute habitat availability increases again.

The weighted habitat availability versus discharge curves are similar in shape for all families, increasing to a peak between $0.15 \mathrm{~m}^{3} \mathrm{~s}^{-1}$ (Chironimidae) and $0.30 \mathrm{~m}^{3} \mathrm{~s}^{-1}$ (Limnephilidae), then declining rapidly to $1 \mathrm{~m}^{3} \mathrm{~s}^{-1}$ and more slowly to $2.25 \mathrm{~m}^{3} \mathrm{~s}^{-1}$. There is then a gentle rise to $4 \mathrm{~m}^{3} \mathrm{~s}^{-1}$ and after that a gentle decline. Again, these reflect the patterns in Figure 4 and the absolute habitat availability data shown in Figures $6 a, 6 c$ and $6 \mathrm{e}$; increases in discharge translate into increases in absolute and weighted habitat availability as long as the discharge increase is accommodated by an increase in width, and the creation of new zones of lower shear stress.

Figure 7a provides a spatial visualisation of excess shear stress for the channel occupied at base flow with on the background the modelled inundation extent of the highest recorded discharge. This shows that almost all of the low flow stream bed has shear stresses that clearly exceed the critical shear stress, notwithstanding the uncertainty in the determination of the latter. Figure $7 \mathrm{~b}$ lends credence to this analysis showing that over a slightly longer timescale than that considered here, the vast majority of the floodplain would be reworked under the current flow regime. It should be emphasised that Figure $7 \mathrm{~b}$ shows a weakness in our approach: there may be evolution in the stream bathymetry during our study period, and hence in hydraulic conditions, and we do not take this into account during our analysis.

\section{Discussion}

The combination of field measurement with habitat modelling for macroinvertebrates allowed identification of how intake flushing may impact instream habitat variations in space and time as compared with what is likely under natural conditions.

In methodological terms, we adopted a mixed methods approach in which standard monitoring and hydraulic modelling methods were combined with a fuzzy habitat analysis. Before we discuss these results, we do wish to emphasise that despite a partial validation, the results of the habitat analysis should be treated with some uncertainty. On the one hand, the method did seem to reproduce a reasonable relationship between habitat availability and abundance for three of the four families studied here. On the other hand, the fact that Baetidae was over predicted in the winter and spring (no flushing) data is a reminder that the model only represents the effects of hydraulics and not other factors (e.g. stream temperature) on habitat availability. Fuzzy models have been found to be sensitive to how rules are set (Adriaenessens et al., 2004) and are reliant upon expert knowledge of the problem at hand (Hernandez-Suarez \& Nejadhashemi, 2018), as illustrated here with the use of the Shields criterion, observations of the lack of armouring, etc. In our application here, we did not include grain-size. There are also crucial issues of scale, especially in the kinds of gravel-bed rivers studied here where scales of just a few $\mathrm{cm}$ may need to be modelled in order to capture both local hydraulic variability and the availability of refugia. Finally, although the analyses are done here at the family scale, there will be within family variation in ecological traits that our application does not capture (in Baetidae, for example, UssegliaPolatera \& Tachet, 1994; Snook \& Milner, 2002). As the Gabbud et al. (2019) data were to family level for the most part, this is the finest taxonomic resolution we could use. This is why the habitat model results in particular should be treated with caution. 
That said, and taken together, the results allow us to evaluate the extent to which more diversified and abundant communities in winter and early spring, as compared with summer, can be attributed to what might be expected naturally in a morphologically dynamic Alpine stream as opposed to flushing of sediment from intakes. In so doing, we also draw some wider implications of these research results.

First, our evidence emphasises the need to consider minimum flows in terms of more than just hydrology (e.g. flow percentiles), the latter still being the case in some countries (e.g. the Swiss Water Law sets the minimum flow to be maintained at a flow abstraction site as the $\mathrm{Q}_{347}$ ). The weighted habitat availability (Figure 3f) tends to reduce for all families above discharges of between $0.15 \mathrm{~m}^{3} \mathrm{~s}^{-1}$ (Chironimidae) and $0.30 \mathrm{~m}^{3} \mathrm{~s}^{-1}$ (Limnephilidae). These discharges are lower than the summer baseflow delivered by krenal and unregulated sources for this reach of river $\left(0.55 \mathrm{~m}^{3} \mathrm{~s}^{-1}\right)$ as all glacier-derived water is abstracted except during flushes. This stream is currently subject to a proposal to require a minimum non-abstracted flow of $0.12 \mathrm{~m}^{3} \mathrm{~s}^{-1}$ at one installation, which would increase the baseflow to between 0.65 and $0.75 \mathrm{~m}^{3} \mathrm{~s}^{-1}$. Assuming the results of the habitat modelling to be correct, this is exactly in the range of flows where absolute habitat availability is increasing marginally (Figures 6a, $6 c, 6 e$ ) but weighted habitat availability is declining rapidly (Figures 6b, 6d, 6f). It emphasises the need to evaluate minimum flow needs in terms of the ecology and not just the hydrology (e.g. a flow percentile) and also to take into account recharge from krenal and unregulated sources.

Second, the wider environmental data emphasise the need to look at not just discharge but also other environmental parameters as here the abstraction of water in itself may well reduce the harshness of the Alpine stream ecosystem. Temperature is commonly identified as a limiting parameter for certain macroinvertebrates in glacially-fed streams (Ward, 1994; Milner et al., 2001). Lower flows aid the recovery of temperature and, in this case, leads to relatively high stream temperatures. With the stream temperatures measured here (Figure 3b) literature (e.g. Milner et al., 2001) suggests that the families studies are unlikely to be temperature limited. At the same time, as it is kryal water that is being abstracted in August, and as nival sources are largely exhausted at this time of year, krenal sources become dominant. The result is turbidity values typically between 20 and 30 NTUs substantially lower than those typical of natural glacier-fed streams in Switzerland (e.g. Malard et al., 2000; Robinson et al., 2001; Uehlinger et al., 2010). The same applies to mean suspended sediment concentrations $\left(378 \pm 11 \mathrm{mgl}^{-1}\right)$, about an order of magnitude lower than the peak suspended sediment concentrations reported for the unregulated streams of glaciers upstream of the study site during similar time periods (Clifford et al., 1995; Swift et al., 2005).

The reduction in turbidity due to the abstraction of suspended sediment rich glacier-derived water means that the euphotic depth of the residual discharges is increased (Figure 3d), except during flushes, and that the development of organic matter ought to be favoured. The greater relative importance of krenal sources might also increase nutrient supply relative to kryal dominated water, although its significance in terms of macroinvertebrate populations is less clear (Malard et al., 2003). The residual discharges also lead to relatively high levels of bed stability as compared with what might be expected under natural flow conditions (Figure 3i). Whilst the absolute habitat availability is lower (Figure 3e) as compared with natural flows, the weighted habitat availability (Figure $3 \mathrm{~g}$ ) is higher, as the residual discharges produce hydraulic conditions more suited to the families studies here. Thus, flow abstraction leads to less harsh and more stable conditions downstream of flow abstraction sites provided there are krenal and/or nival sources capable of providing a minimum flow. This is likely to reduce habitat suitability for macroinvertebrates better adapted to harsher 
environmental conditions (Milner et al., 2001; Niedrist et al., 2018) but increase habitat suitability for generalists. A reduction in environmental harshness is likely to increase overall taxonomic richness (Jacobsen \& Dangles, 2012) and if the target of stream management is measures of stream productivity, flow abstraction is beneficial.

Third, given this result, it is perhaps surprising that Gabbud et al. (2019) found that this stream is severely degraded in macroinvertebrate populations, even in the specialists that might be adapted to the flow variability and turbid water typical of kryal-dominated streams (Milner et al., 2001). Our analysis suggests rapid habitat deterioration during flushing events within the permanent channel (e.g. Figure 4), such that whilst these flushing events do increase absolute habitat availability (Figure 3e), this is through the inundation of new floodplain zones. The main channel itself becomes less suitable at higher discharges (Figures 4, 5) such that weighted habitat availability declines (Figure 3f).

In terms of other environmental parameters, there is only a slight drawdown in temperature directly after flushing. Temperature decline following hydropeaking has been reported (e.g. Bruno et al., 2012) but the decline here is lower than associated with hydropeaking (e.g. Toffolon et al., 2010). It is more the change in hydrograph shape (Figure 3a) and turbidity (Figure 3c) that is more striking. The marked increase in flow peakedness is accompanied by a very rapid increase in turbidity to values much more extreme than are normal for this kind of stream (e.g. Malard et al., 2000; Robinson et al., 2001; Uehlinger et al., 2010), and reflecting previous observations of this system (e.g. Gurnell, 1983; Petts \& Bickertons, 1994). These high turbidity values reflect the release of stored sediment during flushes and effectively counterbalance the reduction in turbidity during low flows by providing very high turbidity during flushes. Mean suspended sediment concentrations are higher than the maxima typical of glaciers upstream (Clifford et al., 1995; Swift et al., 2005) reflecting the combined effect of flushing by glacially derived melt with fine sediment stored in the sediment traps. Euphotic depths then reduce rapidly (Figure 3d). However, the duration of turbidity peak is short and whilst it leads to a marked reduction in the euphotic depth, there is rapid recovery to higher depths once the flush has passed (Figure 3d). The short duration is unlikely then to impact significantly upon the duration of time when organic matter growth is possible. However, the flushing leads to marked destabilisation of the stream bed (Figure 3i, Figure 7a) which is likely to remove organic matter accumulated between flushes. This destabilisation is likely to have a mixed scour and burial effect, as occurs in all braided streams during flushing events (e.g. see Bakker et al., 2019, for an illustration in this system), and it is this scour-burial process, as well as impacts on organic matter accumulation, that may be highly detrimental. Figure 8 illustrates for Baetidae the effects of including only habit preferences alone $(Y)$ as compared with scour-burial and habitat preferences $(G$ and $Y$ ) upon the optimum discharge for habitat at each point in the floodplain shown in Figure 5. Including $G$ reduces the discharge that produces optimal habitat and this reduction is spatially variable, greater in the channel marginal zones where shear stresses increase most as discharge rises. Thus, geomorphic effects of erosion and deposition seem to render the stream more sensitive to discharge change than changes due to habitat preferences alone.

Fourth, the analyses suggested that both the abstraction-flushing regime and the natural flow regime tended to increase absolute habitat availability under higher flows (Figure 3e). This was a function of the braided nature of the stream, which resulted in the spatial reconfiguration of where habitat was most suitable as discharge changed (Figures 4, 5), observed elsewhere for Alpine braided rivers (Arscott et al., 2002; Sukhodolov et al., 2009; Vorste et al., 2016). The increase in absolute but decrease in weighted habitat availability occurs because the rate of creation of newly inundated zones is faster than the rate of 
creation of more suitable habitat in these zones, whilst in the areas inundated at low flows, habitat availability declines rapidly as discharge rises. The low flow inundated zones are also the ones that are most likely to become unstable at high flows (Figure 7a). However, these patterns overlook a more notable consequence of flushing: the discharge (Figure $3 \mathrm{a}$ ) passes from $0.55 \mathrm{~m}^{3} \mathrm{~s}^{-1}$ to $5 \mathrm{~m}^{3} \mathrm{~s}^{-1}$, sometimes $10 \mathrm{~m}^{3} \mathrm{~s}^{-1}$, very rapidly. Whilst there is progressive displacement in where habitat is optimum for all three orders as discharge rises (Figure 5) in practice there is a rapid switch between the low flow and the high flow state, much more rapid than would be the case under natural flow conditions (as also shown in Figures 3e through 3h). Macroinvertebrates can respond in two ways to such changes: burial in the gravel bed or drift (Gayraud et al., 2000). The hyporheic zone is recognised as an important refugee during disturbance (Williams \& Hynes, 1974; Resh et al., 1988; Sedell et al., 1990; Stanford \& Ward, 1993; Malard et al., 2001; Oldmeadow et al., 2010). Macroinvertebrate penetration into substrate is however only possible under two conditions. First, the bed sediment porosity must be sufficient (Maridet et al., 1996). We have no data to evaluate this. Second, the bed should remain relatively stable, with scour no greater than the depth of burial (Dole-Olivier et al., 1997), and not so much deposition that it becomes impossible to emerge after the flush has passed. The high level of bed instability in the low flow zones suggests there is likely to be substantial erosion and deposition during flushes (Figure 7).

Drift has been reported as a possible response to perturbation in glacial streams (Ilg et al., 2001; Saltveit et al., 2001), responsible for $82 \%$ of the stream bed macroinvertebrate colonisation in one case (Townsend \& Hildrew, 1982) but still limiting the development of high levels of taxonomic richness (Jacobsen \& Dangles, 2012). Baetidae, Leuctridae and Limnephilidae typically have their active drift maximum during the night (Brittain \& Eikeland, 1988) while Chironimidae appear to be adapted to both daytime drift (Allan, 1987) and nocturnal drift (Ali \& Mulla, 1979; Stoneburner \& Smock, 1979). Passive (catastrophic) drift results from sudden increases in discharge or substrate movement (Waters, 1961; Lancaster et al., 1996; Oldmeadow et al., 2010; Harby \& Noack, 2013), such as might occur during a flushing event. Drift can occur when sediment is agitated even without transport (Gibbins et al., 2007). In the presence of disturbance, mean drift distances of 3-4 m have been observed in 10 to 15 minutes for Baetidae (Oldmeadow et al., 2010) while others suggest drift is only possible for shorter times, such as 5 to 10 minutes (Bruno et al., 2009). In the example studies here, drift would need to be both out of the low flow channel into anabranches and then back again to avoid stranding. This would need to happen often. The majority of flushes last 30 to 45 minutes (Gabbud et al., 2019), which is twice or even three times the duration that can be endured by macroinvertebrates, and the frequency of habitat condition disturbance can reach more than ten times a day in very extreme cases (Gabbud et al., 2019). Thus, whilst there may be suitable habitat available at flushinginduced high flows, it is not clear macroinvertebrates can migrate rapidly enough to get to such zones. There is evidence that at least some macroinvertebrates can survive the harsh conditions of glacial streams, and our study reach is well downstream of glaciers in zones where under natural flows the families investigated should be present (e.g. Milner et al., 2001). Thus, the fact that Gabbud et al. (2019) did not find macroinvertebrates in the low flow channel during August when flushes are of high frequency may be due to the combination of the bed instability caused by flushing flows coupled with the rapidity of flow change. It explains why macroinvertebrate recovery in this stream occurs as soon as the frequency of flushing events decreases (Gabbud et al., 2019).

To summarise the policy implications arising from this discussion, we argue that introduction of a minimum flow will probably not give the significant habitat improvement 
needed. There are at least three reasons for this. First, given the morphology of the braided river here, increasing minimum flows causes negligible increase in absolute habitat availability and reductions in weighted habitat availability for each order considered (Figure 6). This is because for discharges up to $1 \mathrm{~m}^{3} \mathrm{~s}^{-1}$, substantially greater than the minimum flows required by Swiss law (here the required $Q_{347}$ is about $0.12 \mathrm{~m}^{3} \mathrm{~s}^{-1}$ ), the flow remains within its low flow bed, and the increases in discharge are not expressed in lateral flow expansion. The reason why a hydrological definition of low flow is insufficient in ecological terms is that stream bed morphology conditions the relationship between habitat availability and flow. Research is needed to better understand how braided river morphology conditions the response of macroinvertebrates to discharge change, ideally through the comparison of different Alpine braided rivers. Second, such minimum flows have to come from the sources that are being regulated, which are kryal. Water coming from kryal sources will be colder and turbid, the latter potentially leading to abrasion of accumulated organic matter (Church \& Gilbert, 1975) and light penetration reduction (Robinson et al., 2001). Third, even with some optimisation of a minimum flow, the results emphasise that the real problem is the flushing of sediment. As long as flushing events continue to occur, habitats will be abruptly and frequently degraded and macroinvertebrates will not be able to recover. Flushing at present is needed for two reasons: (1) preventative, by emptying partly filled traps at night so that they don't need to be emptied during the following day, when there is a risk that tourists might be in the stream; and (2) because the sediment trap is full. Both of these issues might be addressed with upstream sediment management and, following Wohl et al. (2015) we argue that this is why this kind of stream needs sediment flows (or sed-flows) as well as e-flows.

\section{Conclusion}

The aim of this study was to explain why flow abstraction and associated intake flushing can lead to dramatic impacts on macroinvertebrate populations in high altitude Alpine streams. Our analyses suggest that whilst the water abstraction itself may reduce the harshness of such streams (in terms of temperature, turbidity, bed stability), flushing events lead to rapid degradation in the habitat conditions found in the channels inundated at low flow, in terms of rapid turbidity increase and increase in the probability of in-channel instability. Basic modelling of habitat preferences suggested that the kind of braided stream studied can have suitable habitat at all discharges (at least until those greater than the discharge which fully occupies the braidplain width). It is the rate of displacement of the sites of suitable habitat across the floodplain, driven by the speed of flushing flow rise and fall, that makes it unlikely that macroinvertebrates can profit from the theoretical resilience associated with the mosaic of braided river habitats. Burial and drift strategies are unlikely to be allow macroinvertebrates to profit from the rapid spatial reorganisation of suitable habitat. We argue that this explains why Gabbud et al. (2019) observed such a strong correlation between the absence of macroinvertebrates during intense flushing and the recovery of macroinvertebrate populations when flushing frequency fell even if the latter was in mid to late autumn.

In restoration terms, the work suggests that recommendations for increasing minimum flows in glaciated catchments need to be sensitive to the extent to which flow from unregulated parts of the basin and from groundwater, provide a minimum flow. If the regulated flows are kryal-sourced, using these to provide minimum flows may degrade low flow habitat through increasing turbidity and reducing stream temperature. Even then, a change in minimum flows should be evaluated with respect to where the current flow is in the relationship 
between absolute/weighted habitat availability and discharge, as this is conditioned by the morphology of the stream bed as well as the size of the flow itself. This observation questions policies that set minimum flows in terms of flow distributions, without taking into account local geomorphological context. Even if it is concluded that a minimum flow is beneficial, it is unlikely that this kind of stream can be restored until there has also been some kind of sediment management, capable of reducing flushing rates. In addition to thinking of e-flows, it is also necessary to think of the kinds of management options that might better manage sediment delivery to intakes.

\section{Acknowledgements}

This work was supported by Swiss National Science Foundation projects PNR70HYDROENV awarded to Paolo Burlando, Peter Molnar, Paolo Perona, Chris Robinson and Stuart Lane and Synergia-SEDFATE awarded to Fritz Schlunegger, Stéphanie Girardclos, Jean-Luc Loizeau, Peter Molnar and Stuart Lane. Grande Dixence SA; Alpiq SA and Hydroexploitation SA provided the raw discharge data. Jean-Noël Saugy and Amélie Savioz assisted with field data collection. Editor Ellen Wohl, an Associate Editor and three reviewers provided extremely valuable comments on a previous version of the manuscript particularly in encouraging us to develop the finer taxonomic resolution in our modelling approach and to attempt validation. 
933

\section{4}

\section{References}

Adriaenssens, V., De Baets, B., Goethals, P. L. M., \& De Pauw, N. (2004). Fuzzy rule-based models for decision support in ecosystem management. Science of the Total Environment, $319,1-12$.

Adriaenssens, V., Goethals, P. L. M., \& De Pauw, N., (2006). Fuzzy knowledge-based models for prediction of Asellus and Gammarus in watercourses in Flanders (Belgium). Ecological Modelling, 195, 3-10.

Ahmadi-Nedushan, B., St-Hilaire, A., Bérubé, M., Ouarda, T. B. M. J., \& Robichaud, E. (2008). Instream flow determination using a multiple input fuzzy-based rule system: a case study. River Research and Applications, 24, 279-292.

Ahmadi-Nedushan, B., St-Hilaire, A., Bérubé, M., Robichaud, É., Thiémonge, N., \& Bobée, B. (2006). A review of statistical methods for the evaluation of aquatic habitat suitability for instream flow assessment. River Research and Applications, 22, 503-523.

Ali, A., \& Mulla, M. S. (1979). Diel periodicity of chironomid larval and pupal drift in a urban flood control channel system. Environmental Entomology, 8, 902-907.

Allan, J. D. (1987). Macroinvertebrate drift in a Rocky Mountain stream. Hydrobiologia, 144, 261-268.

Arscott, D. B., Tockner, K., van der Nat, D., \& Ward, J. V. (2002). Aquatic habitat dynamics along a braided alpine river ecosystem (Tagliamento River, Northeast Italy). Ecosystems, 5, 802-814.

Arthington, A. H. (2012). Environmental Flows: Saving Rivers in the Third Millennium. Berkeley, California: University of California Press.

Arthington, A. H., Bunn, S. E., Poff, N. L., \& Naiman, R. J. (2006). The challenge of providing environmental flow rules to sustain river ecosystems. Ecological Applications, 16, 13111318.

Bakker, M., Antoniazza, G., Odermatt, M., \& Lane, S. N., (2019). Morphological response of an Alpine braided reach to sediment-laden flow events. Journal of Geophysical Research Earth Surface, 124, 1310-1328.

Bakker, M., Costa, A., Silva, T. A., Stutenbecker, L., Girardclos, S., Loizeau, J.-L., Molnar, P., Schlunegger, F., \& Lane, S. N. (2018). Combined flow abstraction and climate change impacts on an aggrading Alpine river. Water Resources Research, 54, 223-242.

Benjankar, R., Tonina, D., \& McKean, J. (2015). One-dimensional and two-dimensional hydrodynamic modeling derived flow properties: impacts on aquatic habitat quality predictions. Earth Surface Processes and Landforms, 40, 340-356.

Benjankar, R., Tonina, D., McKean, J. A., Sohrabi, M. M., Chen, Q., \& Vidergar, D. (2018). Dam operations may improve aquatic habitat and offset negative effects of climate change. Journal of Environmental Management, 213, 126-134. 
Bezinge, A., Clark, M., Gurnell, A., \& Warburton, J. (1989). The management of sediment transported by glacial melt-water streams and its significance for the estimation of sediment yield. Annals of Glaciology, 13, 1-5.

Biggs, B. J. F., \& Close, M. E. (1989). Periphyton biomass dynamics in gravel-bed rivers: the relative effects of flow and nutrients. Freshwater Biology, 22, 209-231.

Biggs, B. J. F., \& Thomsen, H. A. (1995). Disturbance in stream periphyton by perturbations in shear stress; time to structural failure and differences in community resistance. Journal of Phycology, 31, 233-241.

Bovee, K. D. (1986). Development and evaluation of habitat suitability criteria for use in the instream flow incremental methodology (Biological Report No. 21). Fort Collins: U.S. Fish and Wildlife Service.

Bratrich, C., Truffer, B., Jorde, K., Markard, J., Meier, W., Peter, A., Schneider, M., \& Wehrli, B. (2004). Green hydropower: A new assessment procedure for river management. River Research and Applications, 20, 865-882.

Brittain, J. E., \& Eikeland, T. J. (1988). Invertebrate drift - a review. Hydrobiologia, 166, 7793.

Brooker, M. P., \& Hemsworth, R. J. (1978). The effect of the release of an artificial discharge of water on invertebrate drift in the R. Wye, Wales. Hydrobiologia, 59, 155-163.

Brown, L. E., Dickson, N. E., Carrivick, J. L., \& Füreder, L., (2015). Alpine river ecosystem response to glacial and anthropogenic flow pulses. Freshwater Science, 34, 1201-1215.

Bruno, A., Siviglia, A., Carolli, M., \& Maiolini, B. (2012). Multiple drift responses of benthic invertebrates to interacting hydropeaking and thermopeaking waves. Ecohydrology, 6, 511522 .

Bruno, M. C., Maiolini, B., Carolli, M., \& Silveri, L. (2009). Impact of hydropeaking on hyporehic invertebrates in an Alpine stream (Trentino, Italy). Annales de Limnologie International Journal of Limnology, 45, 157-170.

Bunn, S. E., \& Arthington, A. H. (2002). Basic principles and ecological consequences of altered flow regimes for aquatic biodiversity. Environmental Management, 30, 492-507.

Burgherr, P., \& Ward, J. V. (2001). Longitudinal and seasonal distribution patterns of the benthic fauna of an alpine glacial stream (Val Roseg, Swiss Alps). Freshwater Biology, 46, 1705-1721.

Caissie, D., \& El-Jabi, N. (2003). Instream Flow Assessment: From Holistic Approaches to Habitat Modelling. Canadian Water Resources Journal, 28, 173-183.

Carbonneau, P. E., \& Dietrich, J. T. (2017). Cost-effective non-metric photogrammetry from consumer-grade sUAS: implications for direct georeferencing of structure from motion photogrammetry. Earth Surface Processes and Landforms, 42, 473-486.

Céréghino, R., \& Lavandier, P. (1998). Influence of hypolimnetic hydropeaking on the distribution and population dynamics of Ephemeroptera in a mountain stream. Freshwater Biology, 40, 385-399. 
Church, M., \& Gilbert, R. (1975). Proglacial fluvial and lacustrine environments. In Jopling, A. V., \& MacDonald, B. C. (Eds). Glaciofluvial and Glaciolacustrine Sedimentation, vol. 23. Tulsa, the Society of Economic Paleontologists and Mineralogists (SEPM), Special Publication.

Clifford, N. J., Richards, K. S., Brown, R. A., \& Lane, S. N. (1995). Scales of variation of suspended sediment concentration and turbidity in a glacial meltwater stream. Geografiska Annaler, 77A, 45-65.

Cohen, J. (1960). A coefficient of agreement for nominal scales. Educational and Psychological Measurement, 20, 37-46.

Conroy, E., Turner, J. N., Rymszewicz, A., Bruen, M., O'Sullivan, J. J., Lawler, D. M., Stafford, S., \& Kelly-Quinn, M. (2018). Further insights into the responses of macroinvertebrate species to burial by sediment. Hydrobiologia, 805, 399-411.

Cullis, J. D. S., Stanish, L. F., \& McKnight, D. M. (2014). Diel flow pulses drive particulate organic matter transport from microbial mats in a glacial meltwater stream in the McMurdo Dry Valleys, Water Resources Research, 50, 86-97.

Cushman, R. M. (1985). Review of ecological effects of rapidly varying flows downstream from hydroelectric facilities. North American Journal of Fisheries Management, 5, 330-339.

Dole-Olivier, M.-J., Marmonier, P., \& Beffy, J.-L. (1997). Response of invertebrates to lotic disturbance: is the hyporheic zone a patchy refugium? Freshwater Biology, 37, 257-276.

Dolédec, S., Lamouroux, N., Fuchs, U., \& Merigoux, S., (2007). Modelling the hydraulic preferences of benthic macroinvertebrates in small European streams. Freshwater Biology, $52,145-164$.

Dunbar, M. J., Alfredsen, K., \& Harby, A. (2011). Hydraulic-habitat modelling for setting environmental river flow needs for salmonids. Fisheries Management and Ecology, 19, 500517.

Dyson, M., Bergkamp, G., \& Scanlon, J. (2003). Flow. The Essentials of Environmental Flows. Gland, Suisse, Cambridge, UK: IUCN.

ETHZ, VAW. (2017). BASEMENT - Basic Simulation Environment for Computation of Environment and Natural Hazard Simulation (Version version 2.7.0). Zürich. Available on http://www.basement.ethz.ch/.

Fuller, R. L., Doyle, S., Levy, L., Owens, J., Shope, E., Vo, L., Wolyniak, E., Small, M. J., \& Doyle, M. W. (2011). Impact of regulated releases on periphyton and macroinvertebrate communities: The dynamic relationship between hydrology and geomorphology in frequently flooded rivers. River Research and Applications, 27, 630-645.

Füreder, L. (1999). High Alpine Streams: Cold Habitat for Insect Larvae. In Margesin, R., \& Schinner, F. (Eds). Cold Adapted Organisms. Ecology, Physiology, Enzymology and Molecular Biology. Springer Verlag, Berlin.

Füreder, L. (2007). Habitats and bottom fauna of Alpine running waters. International Review of Hydrobiology, 92, 491-53. 
Füreder, L., Schütz, C., Wallinger, M., \& Burger, R. (2001). Physicochemistry and aquatic insects of a glacier-fed and a spring-fed alpine stream. Freshwater Biology, 46, 1673-1690.

Gabbud, C., \& Lane, S. N. (2016). Ecosystem impacts of Alpine water intakes for hydropower: the challenge of sediment management. WIREs Wiley Interdisciplinary Reviews: Water, 3, 41-61.

Gabbud, C., Robinson, C. T., \& Lane, S. N. (2019). Summer is in winter: Disturbance-driven shifts in macroinvertebrate communities following hydroelectric power exploitation. Science of the Total Environment, 650, 2164-2180.

Gallegos, C. L. (2001). Calculating optical water quality targets to restore and protect submersed aquatic vegetation: overcoming problems in partitioning the diffuse attenuation coefficient for photosynthetically active radiation. Estuaries, 24, 381-397.

Garambois, P.-A., Calmant, S., Roux, H., Paris, A., Monnier, J., Finaud-Guyot, P., Samine Montazem, A., \& Santos da Silva, J. (2017). Hydraulic visibility: Using satellite altimetry to parameterize a hydraulic model of an ungauged reach of a braided river. Hydrological Processes, 31, 756-767.

Garcia, A., Jorde, K., Habit, E., Caamaño, D., \& Parra, O. (2011). Downstream environmental effects of dam operations: changes in habitat quality for native fish species. River Research and Applications, 27, 312-327.

Gayraud, S., Philippe, M., \& Maridet, L. (2000). The response of benthic macroinvertebrates to artificial disturbance: drift or vertical movement in the gravel bed of two Sub-Alpine streams? Archiv für Hydrobiologie, 147, 431-446.

Gibbins, C. N., Vericat, D., \& Batalla, R. J. (2007). When is stream invertebrate drift catastrophic? The role of hydraulics and sediment transport in initiating drift during flood events. Freshwater Biology, 52, 2369-2384.

Gooseff, M. N., Van Horn, D., Sudman, Z., McKnight, D. M., Welch, K. A., \& Lyons, W. B. (2016). Stream biogeochemical and suspended sediment responses to permafrost degradation in stream banks in Taylor Valley, Antarctica. Biogeosciences, 13, 1723-1732.

Gore, J. A., Layzer, J. B., \& Mead, J. (2001). Macroinvertebrate instream flow studies after 20 years: a role in stream management and restoration. Regulated Rivers: Research and Management, 17, 527-542.

Gurnell, A. M. (1983). Downstream channel adjustments in response to water abstraction for hydro-electric power generation from alpine glacial melt-water streams. The Geographical Journal, 149, 342-354.

Gurnell, A. M., \& Warburton, J. (1990). The significance of suspended sediment pulses for estimating suspended sediment load and identifying suspended sediment sources in Alpine glacier basins. Hydrology in Mountainous Regions. I - Hydrological Measurements; the Water Cycle, IAHS Publications, 193, 463-470.

Gurnell, A. M., Edwards, P. J., Petts, G. E., \& Ward, J. V. (1999). A conceptual model for alpine proglacial river channel evolution under changing climatic conditions. Catena, 38, 223-242. 
Harby, A., \& Noack, M. (2013). Rapid flow fluctuations and impacts on fish and the aquatic ecosystem. In Maddock, I., Harby, A., Kemp, P, \& Wood, P. (Eds). Ecohydraulics: An Integrated Approach. First Edition. John Wiley \& Sons, Ltd.

Hernandez-Suarez, J. S., \& Nejadhashemi, A. P. (2018). A review of macroinvertebrate- and fish-based stream health modelling techniques. Ecohydrology, 11, e2022.

Hose, G. C., Walter, T., \& Brooks, A. J. (2007). Short-term colonisation by macroinvertebrates of cobbles in main channel and inundated stream bank habitats. Hydrobiologia, 592, 513522 .

Ilg, C., Castella, E., Lods-Crozet, B., \& Marmonier, P. (2001). Invertebrate drift and physicochemical variables in the tributaries of the Mutt, a Swiss glacial stream. Archiv für Hydrobiologie, 151, 335-352.

Jacobsen, D., \& Dangles, O. (2012). Environmental harshness and global richness patterns in glacier-fed streams. Global Ecology and Biogeography, 21, 647-656.

Jorde, K., Schneider, M., \& Zoellner, F. (2000). Analysis of instream habitat qualitypreference functions and fuzzy models. In Wang, Hu (Eds). Stochastic hydraulics. Balkema, Rotterdam, 671-680.

Jorde, K., Schneider, M., Peter, A., \& Zoellner, F. (2001). Fuzzy based models for the valuation of fish habitat quality and instream flow assessment. Proceedings of the 3rd International Symposium on Environmental Hydraulics. 5-8 December, Tempe, AZ.

Kirk, J. T. O. (1994). Light and Photosynthesis in Aquatic Ecosystems. Cambridge University Press, New York.

Lamouroux, N., \& Jowett, I. G. (2005). Generalized Instream Habitat Models. Canadian Journal of Fisheries and Aquatic Sciences, 62, 7-14.

Lancaster, J., \& Hildrew, A. G. (1993). Flow refugia and microdistribution of lotic macroinvertebrates. Journal of the North American Benthological Society, 12, 385-393.

Lancaster, J., Hildrew, A. G., \& Gjerlov, C. (1996). Invertebrate drift and longitudinal transport processes in stream. Canadian Journal of Fisheries and Aquatic Sciences, 53, 572-582.

Lane, S. N., Bakker, M., Balin, D., Lovis, B., \& Regamey, B. (2014). Climate and human forcing of Alpine River flow. In Schleiss, A. J., De Cesare, G., Franca, M. J., Pfister, M. (Eds). River Flow 2014. London: Taylor \& Francis Group, 7-15.

Lane, S. N., Mould, D. C., Carbonneau, R. E., Hardy, R. J., \& Bergeron, N. (2006). Fuzzy modelling of habitat suitability using $2 D$ and $3 D$ hydrodynamic models: Biological challenges. London: Taylor \& Francis Ltd.

Lane, S.N. (2014). Acting, predicting and intervening in a socio-hydrological world. Hydrology and Earth System Science, 18, 927-952.

Lauters, F., Lavandier, P., Lim, P., Sabaton, C., \& Belaud, A. (1996). Influence of hydropeaking on invertebrates and their relationship with fish feeding habits in a Pyrenean river. Regulated Rivers: Research and Management, 12, 563-573. 
Lloyd, D. S., Koenings, J. P., \& La Perriere, J. D. (1987). Effects of turbidity in fresh waters of Alaska. North American Journal of Fisheries Management, 7, 18-33.

Malard, F., Ferreira, D., Doledec, S., \& Ward, J. V. (2003). Influence of groundwater upwelling on the distribution of the hyporheos in a headwater river flood plain. Archiv für Hydrobiologie, 157, 89-116.

Malard, F., Lafont, M., Burgherr, P., \& Ward, J. V. (2001). A comparison of longitudinal patterns in hyporheic and benthic oligochaete assemblages in a glacial river. Arctic, Antarctic, and Alpine Research, 33, 457-466.

Malard, F., Tockner, K., \& Ward, J. V. (2000). Physico-chemical heterogeneity in a glacial riverscape. Landscape Ecology, 15, 679-695.

Maridet, L., Philippe, M., Wasson, J. G., \& Mathieu, J. (1996). Spatial and temporal distribution of macroinvertebrates and trophic variables within the bed sediment of three streams differing by their morphology and riparian vegetation. Archiv für Hydrobiologie, $136,41-46$.

Margot, A., Schädler, B., Sigg, R., \& Weingartner, R. (1992). Influence on rivers by water power stations $(>300 \mathrm{~kW})$ and the lake control. Hydrological Atlas of Switzerland, Plate 5.

Mérigoux, S., \& Dolédec, S. (2004). Hydraulic requirements of stream communities: a case study on invertebrates. Freshwater Biology, 49, 600-613.

Mérigoux, S., Lamouroux, N., Olivier, J. M., \& Dolédec, S. (2009). Invertebrate hydraulic preferences and predicted impacts of changes in discharge in a large river. Freshwater Biology, 54, 1343-1356.

Milner, A. M., \& Petts, G. E. (1994). Glacial rivers: physical habitat and ecology. Freshwater Biology, 32, 295-307.

Milner, A. M., Brittain, J. E., Castella, E., \& Petts, G. E. (2001). Trends of macroinvertebrate community structure in glacier-fed rivers in relation to environmental conditions: a synthesis. Freshwater Biology, 46, 1833-1847.

Möbes-Hansen, B., \& Waringer, J. A. (1998). The influence of hydraulic stress on microdistribution patterns of zoobenthos in a sandstone brook (Weidlingbach, Lower Austria). International Review of Hydrobiology, 83, 381-396.

Modenutti, B., Pérez, G., Balseiro, E., \& Queimaliños, C. (2000). The relationship between light attenuation, chlorophyll a and total suspended solids in a Southern Andes glacial lake. Verhandlungen des Internationalen Verein Limnologie, 27, 1-4.

Moog, O. (1993). Quantification of daily peak hydropower effects on aquatic fauna and management to minimize environmental impacts. Regulated Rivers: Research and Management, 8, 5-14.

Mouton, A. M., Jowett, I., Goethals, P. L. M., \& De Baets, B. (2009). Prevalence-adjusted optimisation of fuzzy habitat suitability models for aquatic invertebrate and fish species in New Zealand. Ecological Informatics, 4, 215-225. 
Mouton, A., De Baets, B., \& Goethals, P. (2013). Data-driven fuzzy habitat models: impact of performance criteria and opportunities for ecohydraulics. Chapter 5 in Maddock, I., Harby, A., Kemp P., \& Wood, P. (Eds). Ecohydraulics: An Integrated Approach. Wiley, Chichester, 31-74.

Müller, M. P., McKnight, D. M., Cullis, J. D., Greene, A., Vietti, K., \& Liptzin, D. (2009). Factors controlling streambed coverage of Didymosphenia germinate in two regulated streams in the Colorado front range. Hydrobiologia, 630, 207-218.

Niedrist, G. H., Cantonati, M., \& Fuereder, L. (2018). Environmental harshness mediates the quality of periphyton and chironomid body mass in alpine streams. Freshwater Science, 37, 519-533.

OFEV Office Fédéral de l'Environnement (2010). Méthodes d'analyse et d'appréciation des cours d'eau; Macroozoobenthos - niveau R (région). Berne: Author.

Oldmeadow, D. F., Lancaster, J., \& Rice, S. P. (2010). Drift and settlement of stream insects in a complex hydraulic environment. Freshwater Biology, 55, 1020-1035.

Orr, C. H., Kroiss, S. J., Rogers, K. L., \& Stanley, E. H. (2008). Downstream benthic responses to small dam removal in a coldwater stream. River Research and Applications, 24, 804-822.

Pan, F., Wang, C., \& Xi, X. (2016). Constructing river stage-discharge rating curves using remotely sensed river cross-sectional inundation areas and river bathymetry. Journal of Hydrology, 540, 670-687.

Parasiewicz, P., Schmutz, S., \& Moog, O. (1998). The effect of managed hydropower peaking on the physical habitat, benthos and fish fauna in the River Bregenzerach in Austria. Fisheries Management and Ecology, 5, 403-417.

Petts, G. E. (2009). Instream-flow science for sustainable river management. Journal of the American Water Resources Association, 45, 1071-1086.

Petts, G. E., \& Bickerton, M. A. (1994). Influence of water abstraction on the macroinvertebrate community gradient within a glacial stream system: La Borgne d'Arolla, Valais, Switzerland. Freshwater Biology, 32, 375-386.

Petts, G. E., \& Gurnell, A. M. (2005). Dams and geomorphology: Research progress and future directions. Geomorphology, 70, 27-47.

Poff, N. L., \& Zimmerman, J. K. N. (2010). Ecological responses to altered flow regimes: a literature review to inform the science and management of environmental flow. Freshwater Biology, 55, 195-205.

Poff, N. L., Allan, J. D., Bain, M. B., Prestegaard, K. L., Richter, B. D., Sparks, R. E., \& Stromberg, J. C. (1997). The natural flow regime. BioScience, 47, 769-784.

Poff, N. L., Tharme, R. E., \& Arthington, A. H. (2017). Chapter 11 - Evolution of Environmental Flows Assessment Science, Principles, and Methodologies. In Horne, A., Webb, A., Stewardson, M., Richter, B., \& Acreman, M. Water for the Environment - From Policy and Science to Implementation and Management. Academic Press, 203-236. 
Rae, R., Howard-Williams, C., Hawes, I., Schwarz, A. M., \& Vincent, W. F. (2001). Penetration of solar ultraviolet radiation into New Zealand lakes: Influence of dissolved organic carbon and catchment vegetation. Limnology, 2, 79-89.

Resh, V. H., Brown, A. V., Covich, A. P., Gurtz, M. E., Li, H. W., Minshall, G. W., Reice, S. R., Sheldon, A. L., Wallace, J. B., \& Wissmar, R. C. (1988). The role of disturbance in stream ecology. Journal of the North American Benthologica Society, 7, 433-455.

Robinson, C. T., Uehlinger, U., \& Hieber, M. (2001). Spatiotemporal variation in macroinvertebrate assemblages of glacial streams in the Swiss Alps. Freshwater Biology, $46,1663-1672$.

Rose, K. C., Hamilton, D. P., Williamson, C. E., McBride, C. G., Fischer, J. M., Olson, M. H., Saros, J. E., Allan, M. G., \& Cabrol, N. (2014). Light attenuation characteristics of glaciallyfed lakes. Journal of Geophysical Research: Biogeosciences, 119, 1446-1457.

Saltveit, S. J., Haug, I., \& Brittain, J. E. (2001). Invertebrate drift in a glacial river and its nonglacial tributary. Freshwater Biology, 46, 1777-1789.

Schmutz, S., Bakken, T. H., Friedrich, T., Greimel, F., Harby, A., Jungwirth, M., Melcher, A., Unfer, G., \& Zeiringer, B. (2015). Response of fish communities to hydrological and morphological alterations in hydropeaking rivers of Austria. River Research and Applications, 31, 919-930.

Schneider, M., Kopecki, I., Tuhtan, J., Sauterleute, J. F., Zinke, P., Bakken, T. H., \& Merigoux, S. (2017). A fuzzy rule-based model for the assessment of macrobenthic habitats under hydropeaking impact: fuzzy rule-based model for benthic habitats. River Research and Applications, 33, 377-387.

Schuil ing, L., Feld, C. K., \& Graf, W. (2016). Effects of hydro- and thermopeaking on benthic macroinvertebrate drift. Science of the Total Environment, 573, 1472-1480.

Schülting, L., Feld, C. K., Zeiringer, B., Huđek, H., \& Graf, W. (2019). Macroinvertebrate drift response to hydropeaking: An experimental approach to assess the effect of varying ramping velocities. Ecohydrology, 12:e2032.

Sedell, J. R., Reeves, G. H., Hauer, F. R., Stanford, J. A., \& Hawkins, C. P. (1990). Role of refugia in recovery from disturbances: modern fragmented and disconnected river systems. Environmental Management, 14, 711-724.

Simeonov, J. A., Holland, K. T., Calantoni, J., \& Anderson, S. P. (2013). Calibrating discharge, bed friction, and datum bias in hydraulic models using water level and surface current observations. Water Resources Research, 49, 8026-8038.

Smith, L. C. (1997). Satellite remote sensing of river inundation area, stage, and discharge: a review. Hydrological Processes, 11, 1427-1439.

Smokorowski, K. E., Metcalfe, R. A., Finucan, S. D., Jones, N., Marty, J., Power, M., Pyrce, R. S., \& Steele, R. (2011). Ecosystem level assessment of environmentally based flow restrictions for maintaining ecosystem integrity: A comparison of a modified peaking versus unaltered river. Ecohydrology, 4, 791-806. 
Snook, D. L., \& Milner, A. M. (2002). Biological traits of macroinvertebrates and hydraulic conditions in a glacier-fed catchment (French Pyrenees). Archiv Für Hydrobiologie, 153, 245-271.

Stanford, J. A., \& Ward, J. V. (1993). An ecosystem perspective of alluvial rivers: Connectivity and the hyporheic corridor. Journal of the North American Benthological Society, 12, 48-60.

Statzner, B., \& Müller, R. (1989). Standard hemispheres as indicators of flow characteristics in lotic benthos research. Freshwater Biology, 21, 445-459.

Stoneburner, D. L., \& Smock, L. A. (1979). Seasonal fluctuations of macroinvertebrate drift in a South Carolina Piedmont stream. Hydrobiologia, 63, 49-56.

Strayer, D. L., Power, M. E., Fagan, W. F., Pickett, S. T. A., \& Belnap, J. (2003). A classification of ecological boundaries. Bioscience, 53, 723-729.

Sukhodolov, A., Bertoldi, W., Wolter, C., Surian, N., \& Tubino, M. (2009). Implications of channel processes for juvenile fish habitats in Alpine rivers. Aquatic Sciences, 71, 338-349.

Swift, D. A., Nienow, P. W., \& Hoey, T. B. (2005). Basal sediment evacuation by subglacial meltwater: suspended sediment transport from Haut Glacier d'Arolla, Switzerland. Earth Surface Processes and Landforms, 30, 867-883.

The Brisbane Declaration (2007). Environmental Flows are Essential for Freshwater Ecosystem Health and Human Well-Being. 10 ${ }^{\text {th }}$ International River Symposium and International Environmental Flows Conference, Brisbane, Australia.

Theodoropoulos, C., Skoulikidis, N., Rutschmann, P., \& Stamou, A. (2018). Ecosystem-based environmental flow assessment in a Greek regulated river with the use of 2D hydrodynamic habitat modelling. River Research and Applications, 34, 538-547.

Toffolon, M., Siviglia, A., \& Zolelli, G. (2010). Thermal wave dynamics in rivers affected by kydropeaking. Water Resources Research, 46, W0853.

Tonina, D., \& Jorde, K. (2013). Hydraulic modelling approaches for ecohydraulic studies: 3D, 2D, 1D and non-numerical models. Chapter 3 in Maddock, I., Harby, A., Kemp P. \& Wood, P. (Eds). Ecohydraulics: An Integrated Approach. Wiley, Chichester, 93-107.

Townsend, C. R., \& Hildrew, P. P. (1982). The macro-invertebrate fauna in a high Andean stream. Hydrobiologia, 89, 141-151.

Uehlinger, U., Robinson, C. T., Hieber, M., \& Zah, R. (2010). The physico-chemical habitat template for periphyton in alpine glacial streams under a changing climate. Hydrobiologia, 657, 107-121.

Uehlinger, U., Zah, R., \& Bürgi, H. (1998). The Val Roseg project: temporal and spatial patterns of benthic algae in an Alpine stream ecosystem influenced by glacial runoff. International Association of Hydrological Sciences Special Publication, 248, 419-424.

Usseglio-Polatera, P., \& Tachet, H. (1994). Theoretical habitat templets, species traits, and species richness: Plecoptera and Ephemeroptera in the Upper Rhône River and its floodplain. Freshwater Biology, 31, 357-375. 
Vadas, R. L., \& Orth, D. J. (2001). Formulation of habitat suitability models for streams fish guilds: do the standard methods work? Transactions of the American Fisheries Society, 130, 217-235.

Van Broekhoven, E., Adriaenssens, V., \& De Baets, B. (2007). Interpretability-preserving genetic optimization of linguistic terms in fuzzy models for fuzzy ordered classification: An ecological case study. International Journal of Approximate Reasoning, 44, 65-90.

Van Broekhoven, E., Adriaenssens, V., De Baets, B., \& Verdonschot, P. F. M. (2006). Fuzzy rule-based macroinvertebrate habitat suitability models for running waters. Ecological Modelling, 198, 71-84.

Vetsch, D., Siviglia, A., Caponi, F., Ehrbar, D., Gerke, E., Kammerer, S., Koch, A., Peter, S., Vanzo, D., Vonwiller, L., Facchini, M., Gerber, M., Volz, C., Farshi, D., Mueller, R., Rousselot, P., Veprek, R., \& Faeh, R. (2017). System Manuals of BASEMENT, Version 2.7. Laboratory of Hydraulics, Glaciology and Hydrology (VAW). ETH Zurich.

Vorste, R. V., Corti, R., Sagouis, A., \& Datry, T. (2016). Invertebrate communities in gravelbed, braided rivers are highly resilient to flow intermittence. Freshwater Science, 35, 164177.

Wang, L. (1994). Adaptive fuzzy systems and control. Prentice Hall, New Jersey, 232 pp.

Ward, J. V. (1994). Ecology of alpine stream. Freswater Biology, 32, 277-294.

Waters, T. F. (1961). Standing crop and drift of stream bottom organisms. Ecology, 42, 532537.

Westaway, R. M., Lane, S. N., \& Hicks, D. M. (2000). The development of an automated correction procedure for digital photogrammetry for the study of wide, shallow, gravel-bed rivers. Earth Surface Processes and Landforms, 25, 209-226.

Westaway, R. M., Lane, S. N., \& Hicks, D. M. (2001). Remote sensing of clearwater, shallow, gravel-bed rivers using digital photogrammetry. Photogrammetric Engineering and Remote Sensing, 67, 1271-1282.

Williams, D. D., \& Hynes, H. B. N. (1974). The occurrence of benthos deep in the substratum of a stream. Freshwater Biology, 4, 233-256.

Williams, R. D., Brasington, J., Hicks, M., Measures, R., Rennie, C. D., \& Vericat, D. (2013). Hydraulic validation of two-dimensional simulations of braided river flow with spatially continuous aDcp data, Water Resources Research, 49, 5183-5205.

Wohl, E., Lane, S. N., \& Wilcox, A. C. (2015). The science and practice of river restoration. Water Resources Research, 51, 5974-5997.

Wood, P. J., Toone, J., Greenwood, M. T., \& Armitage, P. D., (2005). The response of four lotic macroinvertebrate taxa to burial by sediments. Archiv für Hydrobiologie, 163, 145-162. 


\section{Captions}

1316 Figure 1: The Arolla river basin in the Swiss Alps with the water intakes (left) and the focus study area at Satarma (right).

1317

1318

1319

1320

1321

1322

1323

1324

1325

1326

1327

1328

1329

1330

1331

1332

1333

1334

1335

1336

1337

1338

1339

1340

1341

1342

1343

Figure 2: Measured abundance versus mean habitat score with grey lines showing the standard deviation of the habitat score in the main channel zone; the data points are classed in two ways, in Figure $2 a$ by time period and in Figure $2 b$ by family.

Figure 2: Time series of the variables measured and modelled for 9 days from the $6^{\text {th }}$ of August 201: a) discharge under flushing (in red) and natural (in black) conditions $\left[\mathrm{m}^{3} \mathrm{~s}^{-1}\right]$; b) temperature $\left[{ }^{\circ} \mathrm{C}\right]$; c) Turbidity [NTUs]; d) euphotic depth [m], the depth at which 95\% of incoming light can penetrate to the stream bed; e) absolute habitat availability with a flushing regime for the four modelled families; f) weighted habitat availability with a flushing regime for the four modelled families; g) absolute habitat availability with a natural regime for the four modelled families; $h$ ) weighted habitat availability with a natural regime for the four modelled families; i) percentage of the bed that is inundated at base flow $\left(0.55 \mathrm{~m}^{3} \mathrm{~s}^{-}{ }^{1}\right)$ that is active given the discharge time-series in Figure $3 a ; j)$ the inundated area where the water depth is lower than the euphotic depth and light can reach the stream bed; $k$ ) the percentage of the total inundated area where the water depth is lower than the euphotic depth and light can reach the stream bed.

Figure 3: Spatial evolution of habitat suitability index according to discharge for the family Leuctridae using the fuzzy habitat modelling approach described in the text.

Figure 4: The discharge (Q) at each point in the floodplain that produces the optimum habitat suitability at that point.

Figure 5: Absolute (left) and Weighted (right) Habitat Availability for: the four families studied here: (a) and (b), Baetidae; (c) and (d) Chironomidae; (e) and (f) Leuctridae; and (g) and (h) Limnephilidae.

Figure 7: a) A map of modelled peak shear stress as multiples of the critical (Shields) shear stress for the highest discharge simulated, showing those zones inundated at low flow; b) DEM of difference between the $26^{\text {th }}$ of July and the $12^{\text {th }}$ of August 2016 with in blue $=$ positive change $=$ deposition and in red $=$ negative change $=$ erosion, with LoD $=$ Limit of Detection of change $(=0.13 \mathrm{~m})$.

Figure 8: Change in optimal discharge for Baetidae when the model is run with habitat preferences only (Y) as opposed to both habitat preferences and geomorphic suitability ( $Y$ and G, Figure $5 a$ ). 


\section{Tables}

1345 Table 1: Hydraulic model calibration with highest interpolation results; $K=$ Kappa; $m=$ Slope of the regression; $r=$

Correlation.

\begin{tabular}{ccccc}
\hline $\begin{array}{c}\text { Discharge } \\
\left(\mathrm{m}^{3} \mathrm{~s}^{1}\right)\end{array}$ & $\begin{array}{c}\text { Manning's } \\
n\end{array}$ & $\kappa$ & $m$ & $r$ \\
\hline 0.5 & 0.04 & 0.837 & 2.64 & 0.731 \\
0.5 & 0.05 & 0.845 & 1.989 & 0.729 \\
0.5 & 0.06 & 0.868 & 1.253 & 0.726 \\
0.55 & 0.04 & 0.881 & 1.122 & 0.713 \\
0.55 & 0.05 & 0.879 & 1.068 & 0.722 \\
$\mathbf{0 . 5 5}$ & $\mathbf{0 . 0 6}$ & $\mathbf{0 . 8 7 6}$ & $\mathbf{1 . 0 2}$ & $\mathbf{0 . 7 3 2}$ \\
0.55 & 0.07 & 0.87 & 0.968 & 0.736 \\
0.55 & 0.08 & 0.868 & 1.125 & 0.754 \\
0.6 & 0.04 & 0.878 & 1.254 & 0.762 \\
0.6 & 0.05 & 0.876 & 1.026 & 0.727 \\
0.6 & 0.06 & 0.753 & 0.218 & 0.701
\end{tabular}

Table 2: The (symmetrical) definition of habitat classes in relation to the rule set defined in [7].

\begin{tabular}{|c|c|c|c|}
\hline Symmetrical & $\begin{array}{c}\text { Y Poor } \\
\text { (presence } \\
\text { rarely found) }\end{array}$ & Y Medium & $\begin{array}{c}\text { Y Good } \\
\text { (presence } \\
\text { often found) }\end{array}$ \\
\hline $\begin{array}{l}\text { G Poor } \\
\text { (risk of burial or } \\
\text { scour) }\end{array}$ & $\begin{array}{c}\text { Unsuitable Habitat } \\
0\end{array}$ & $\begin{array}{c}\text { Very Poor Habitat } \\
1\end{array}$ & $\begin{array}{c}\text { Poor Habitat } \\
2\end{array}$ \\
\hline G Medium & $\begin{array}{c}\text { Very Poor Habitat } \\
1\end{array}$ & $\begin{array}{c}\text { Good Habitat } \\
3\end{array}$ & $\begin{array}{c}\text { Very Good Habitat } \\
4\end{array}$ \\
\hline $\begin{array}{l}\text { G Good } \\
\text { (fines washed out } \\
\text { but no risk of } \\
\text { catastrophic scour) }\end{array}$ & $\begin{array}{c}\text { Poor Habitat } \\
2\end{array}$ & $\begin{array}{c}\text { Very Good Habitat } \\
4\end{array}$ & $\begin{array}{l}\text { Excellent Habitat } \\
5\end{array}$ \\
\hline
\end{tabular}


Figure1. 


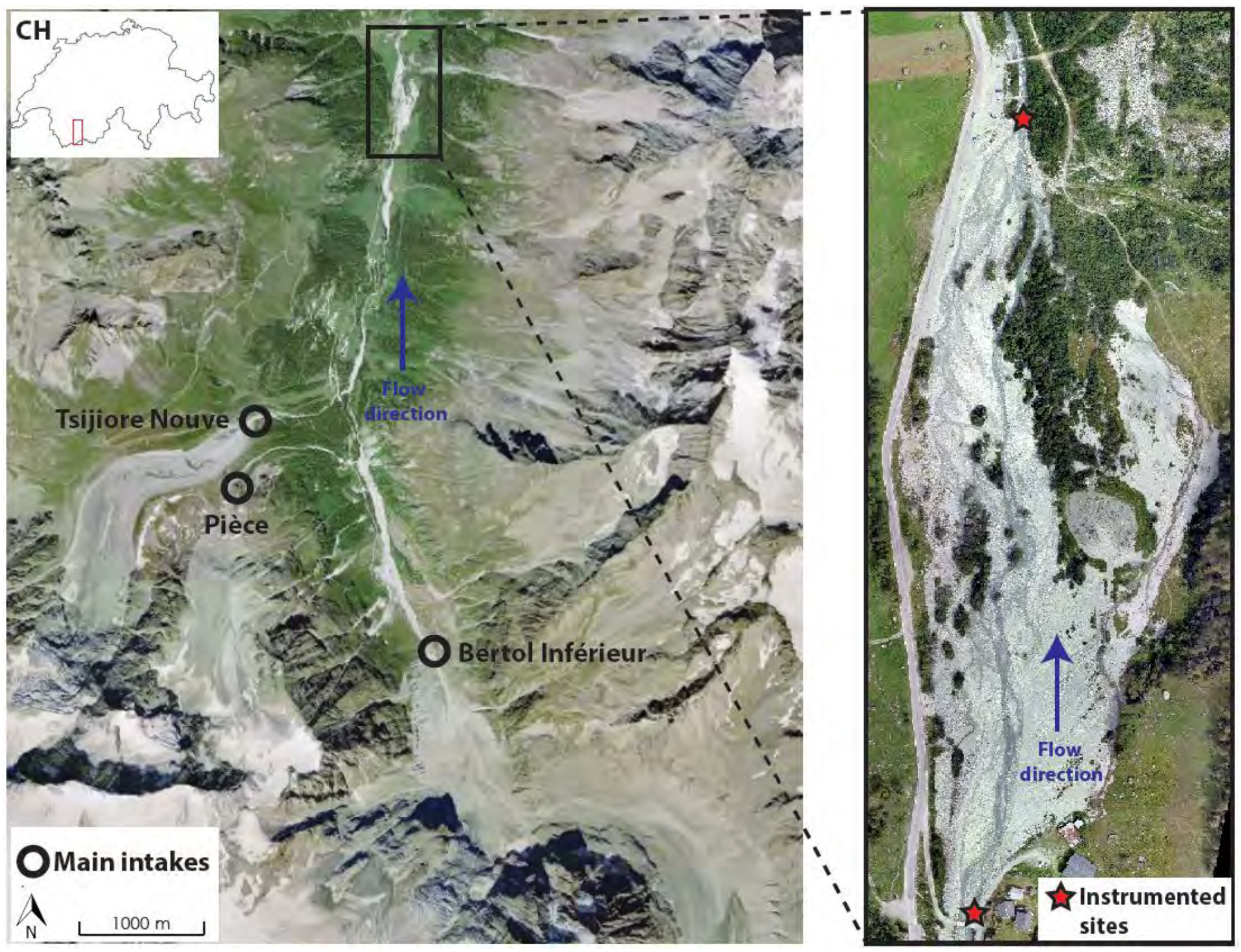


Figure2. 

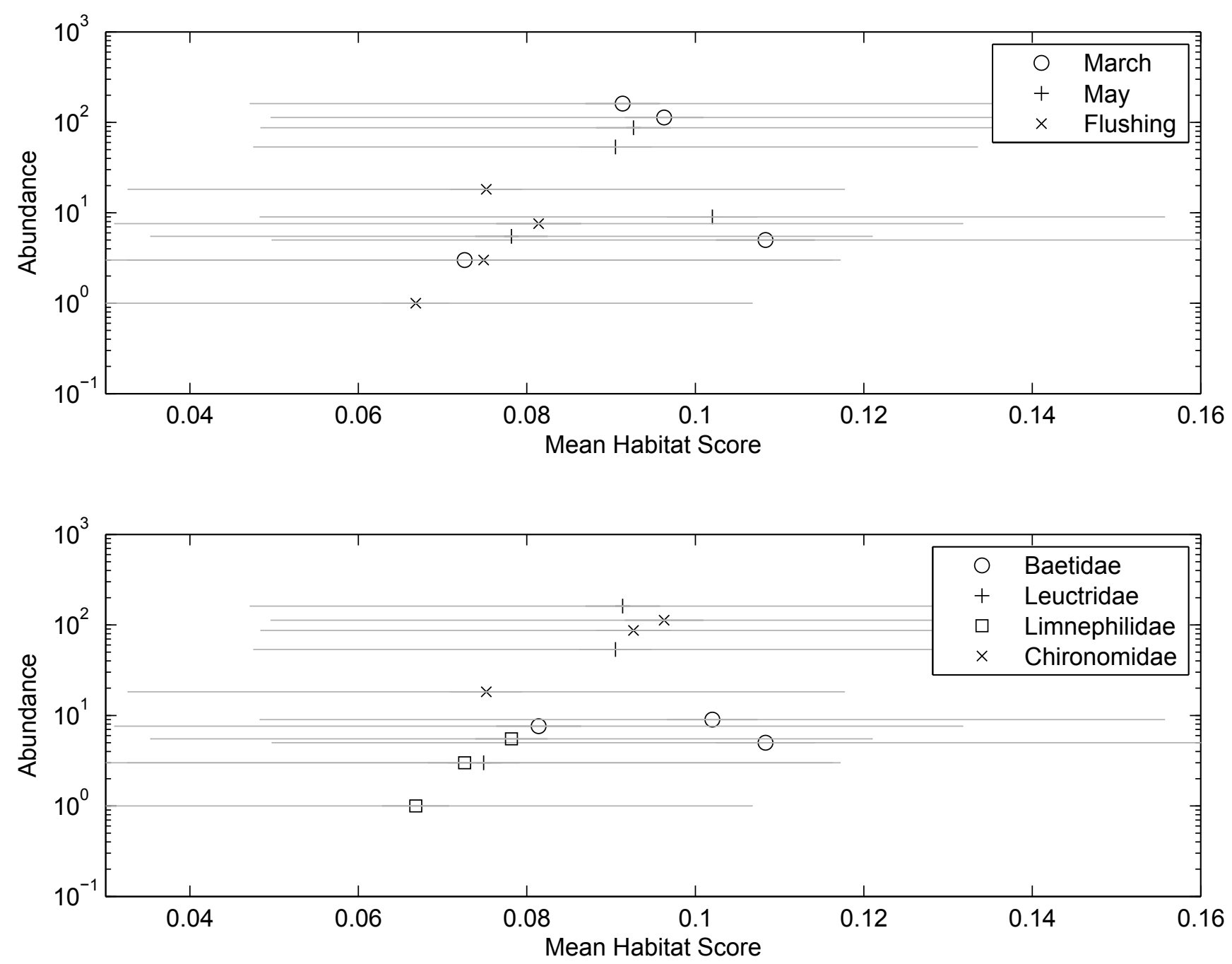
Figure3ai. 

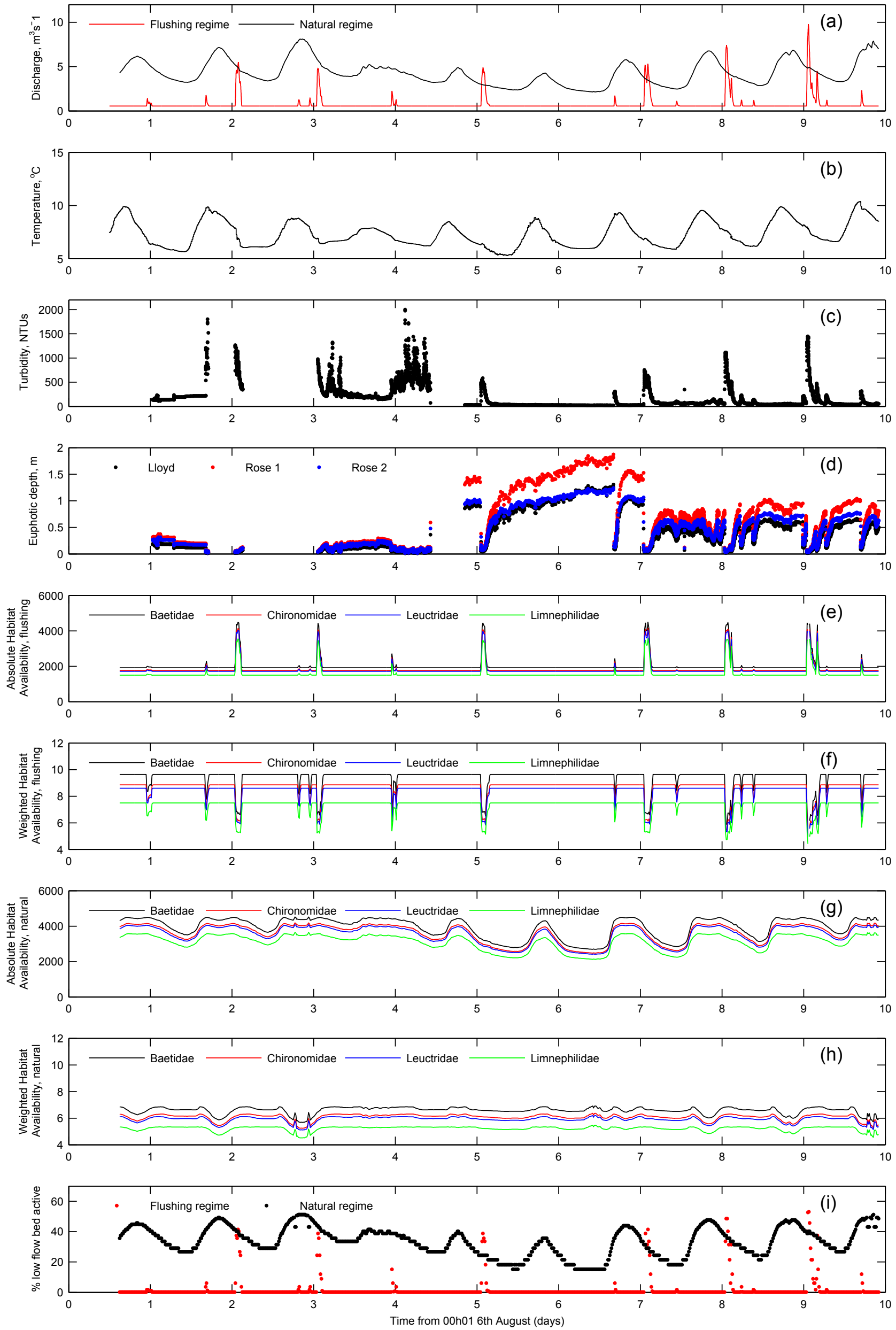
Figure3jk. 

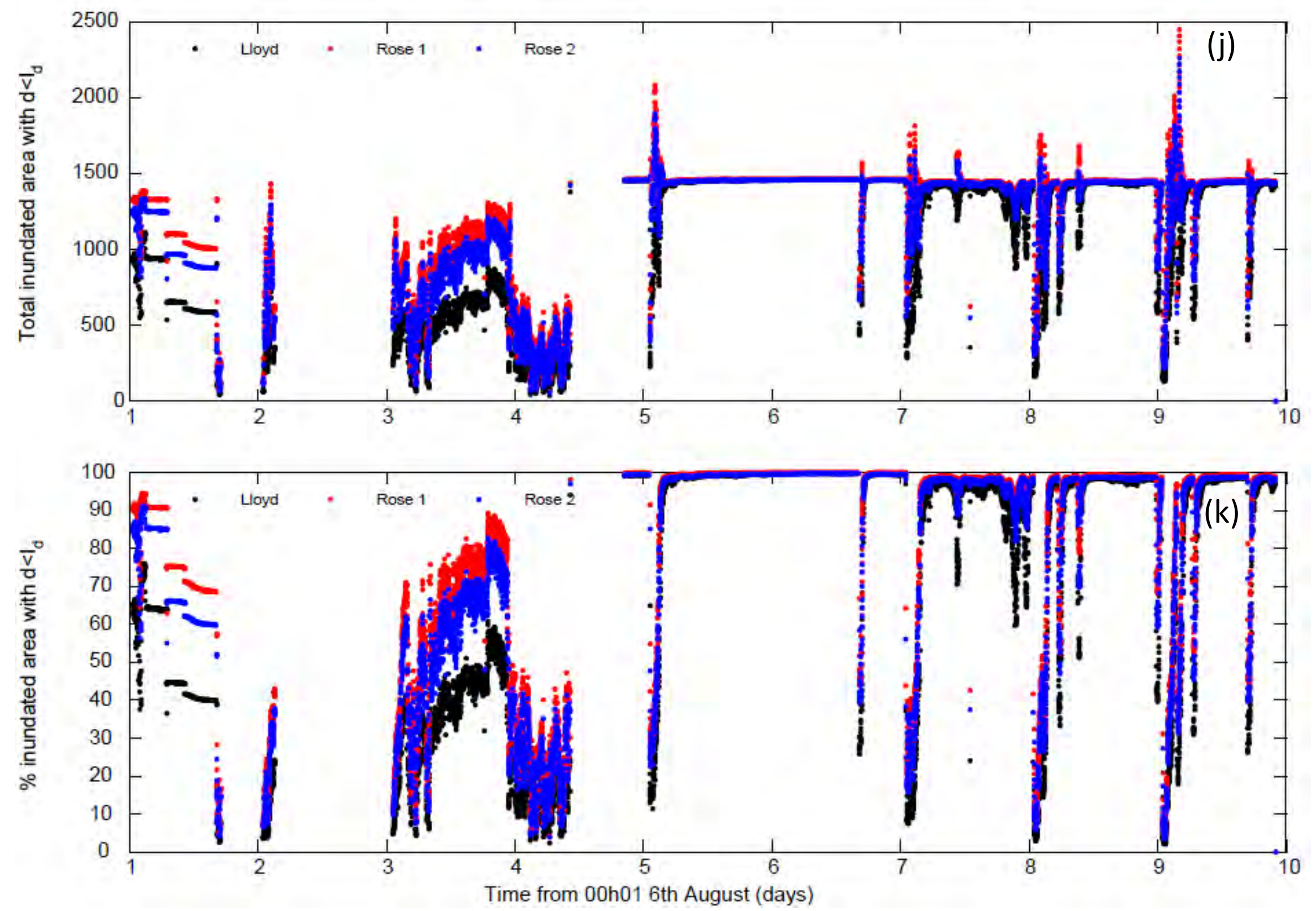
Figure4. 


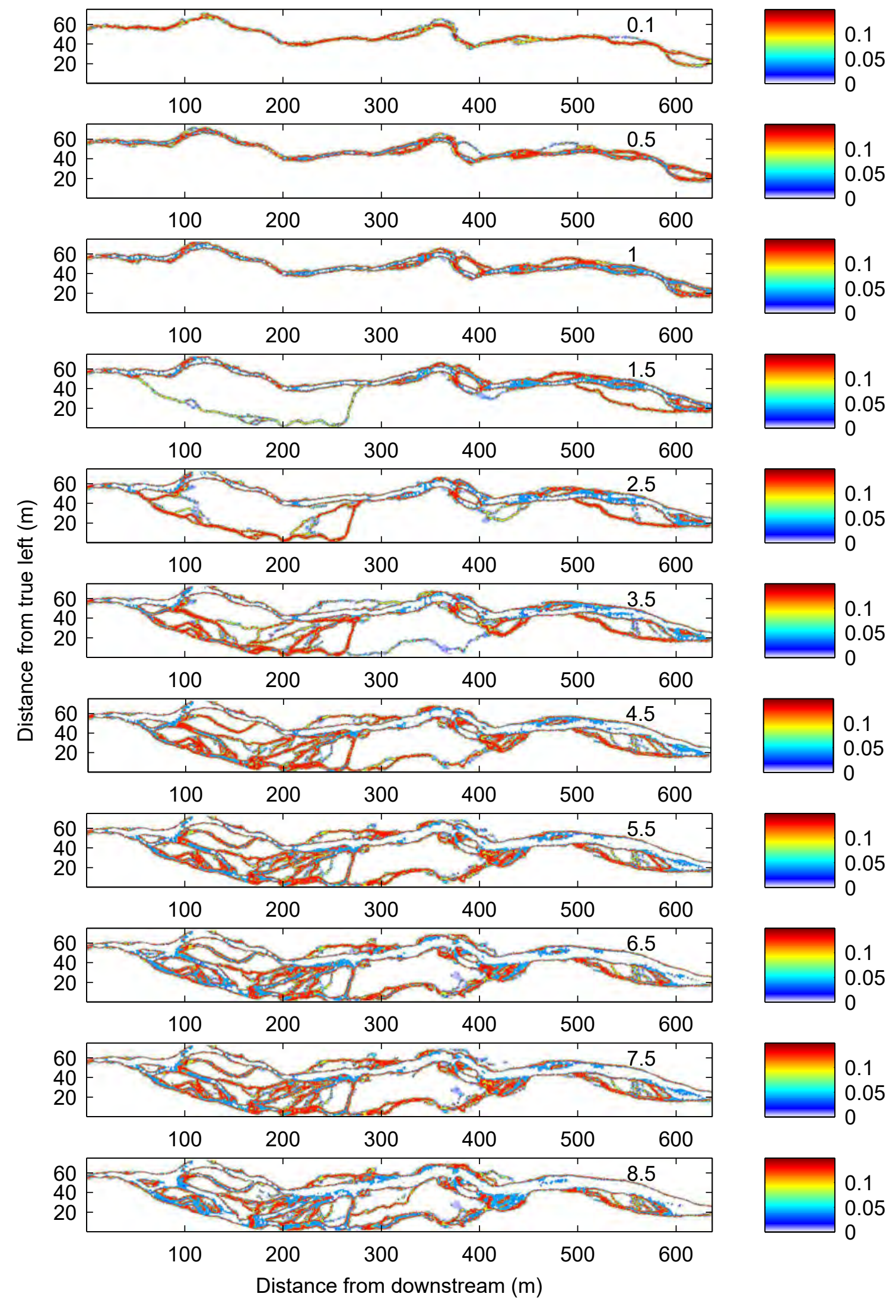


Figure5. 

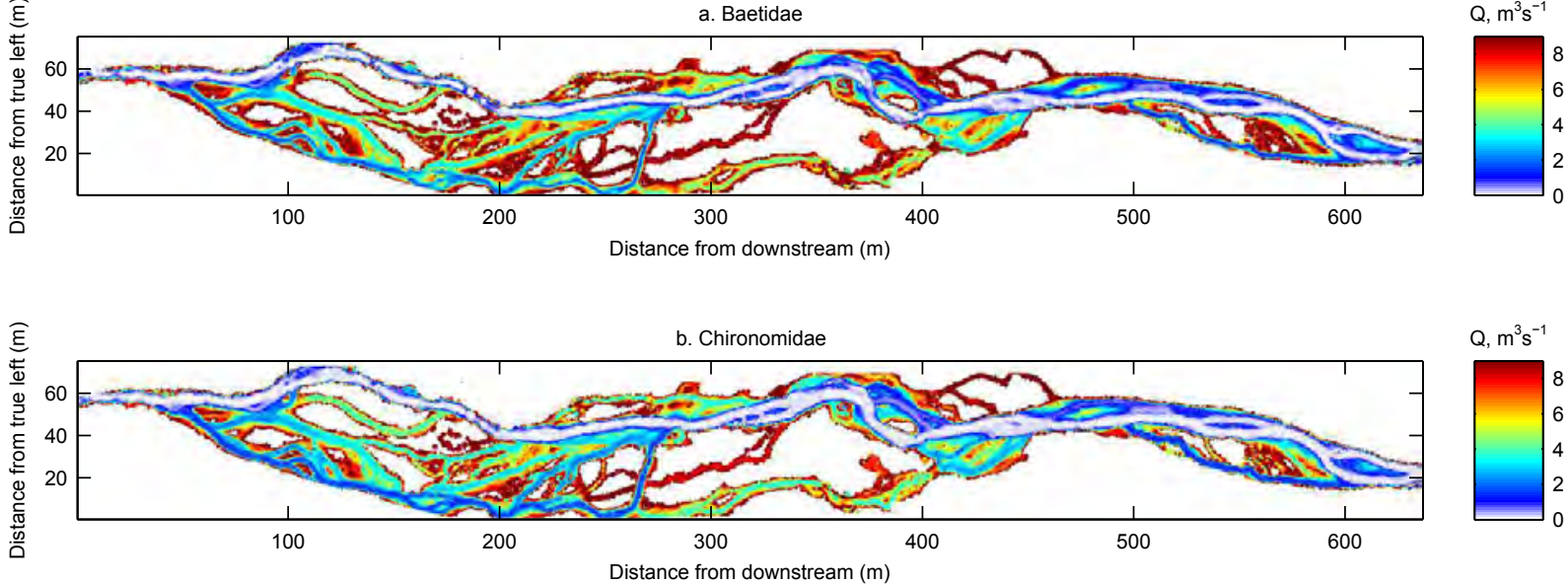

$\mathrm{Q}, \mathrm{m}^{3} \mathrm{~s}^{-1}$
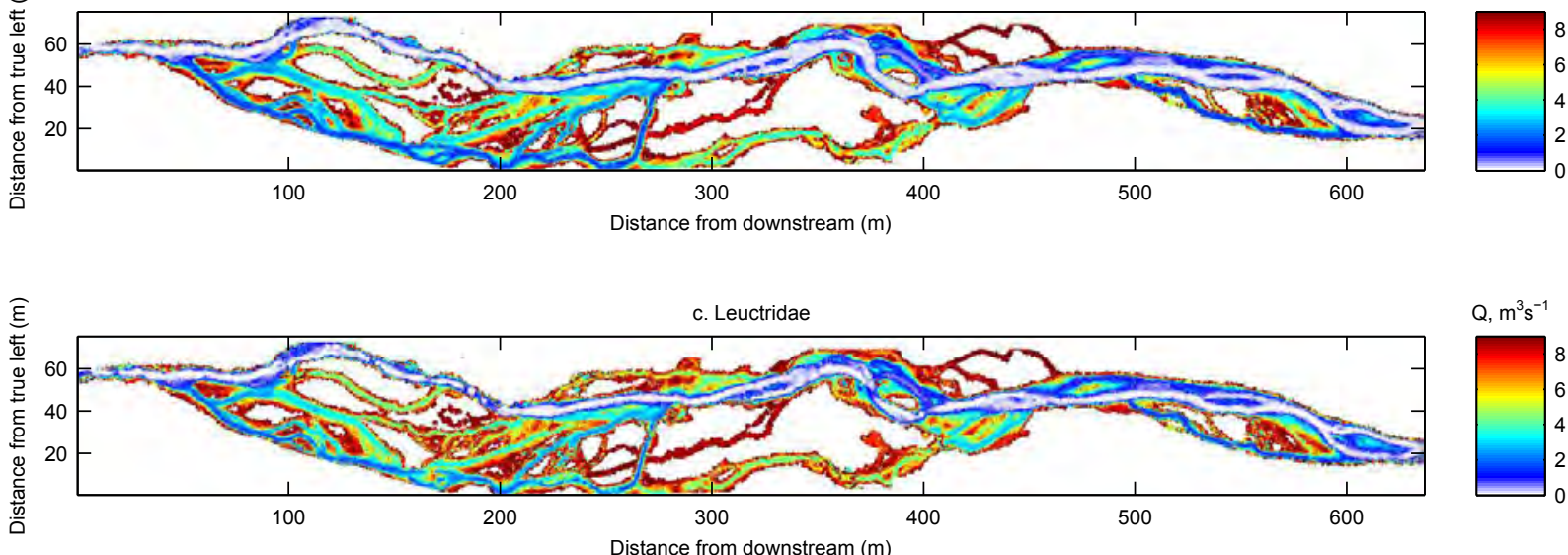

$\mathrm{Q}, \mathrm{m}^{3} \mathrm{~s}^{-1}$

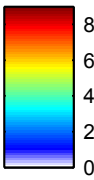

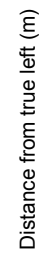

d. Limnephilidae

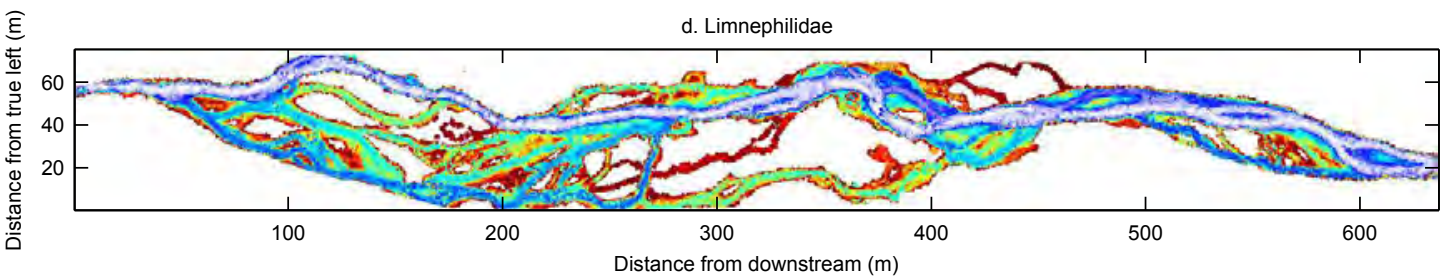

$\mathrm{Q}, \mathrm{m}^{3} \mathrm{~s}^{-1}$

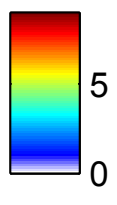


Figure6. 

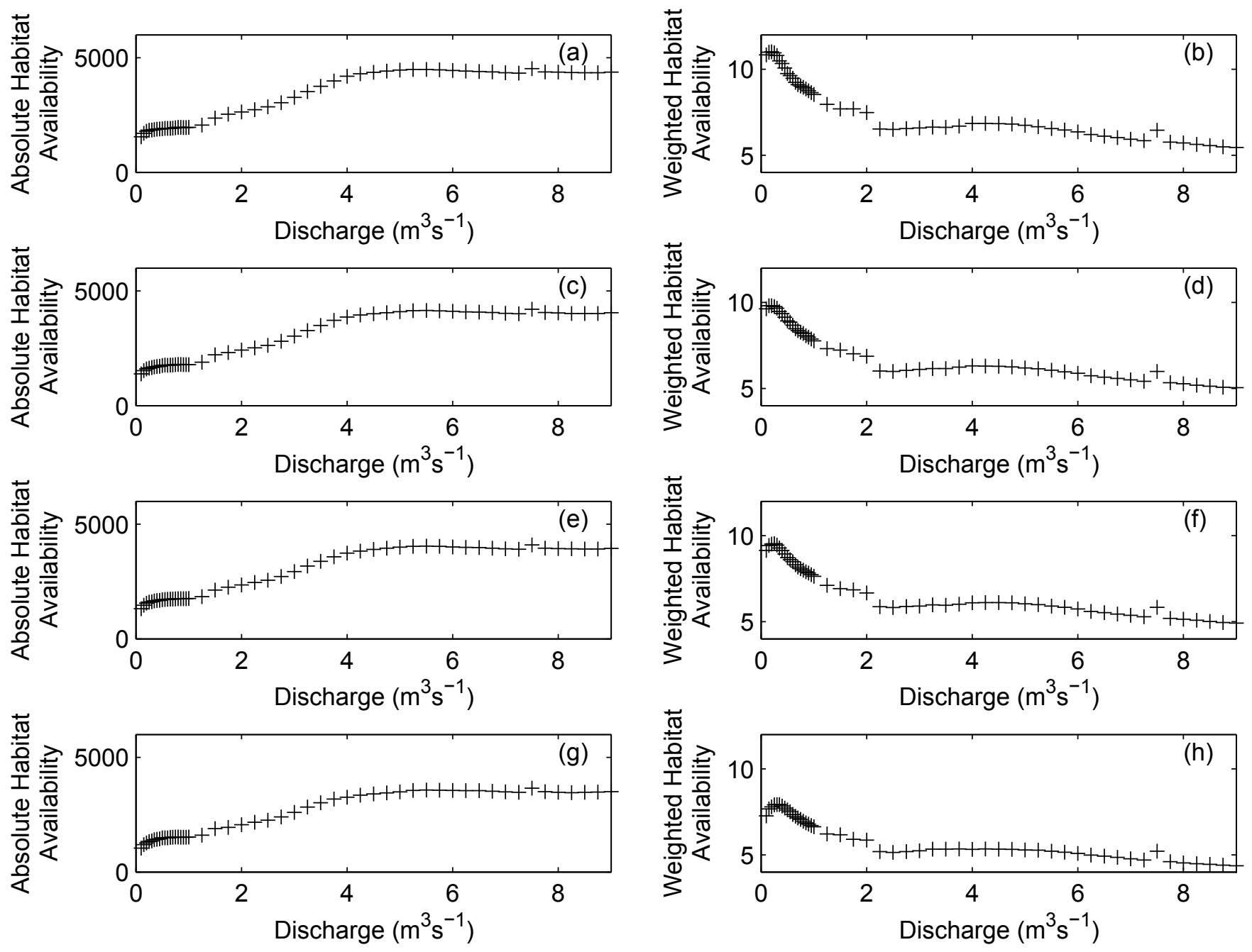
Figure7. 


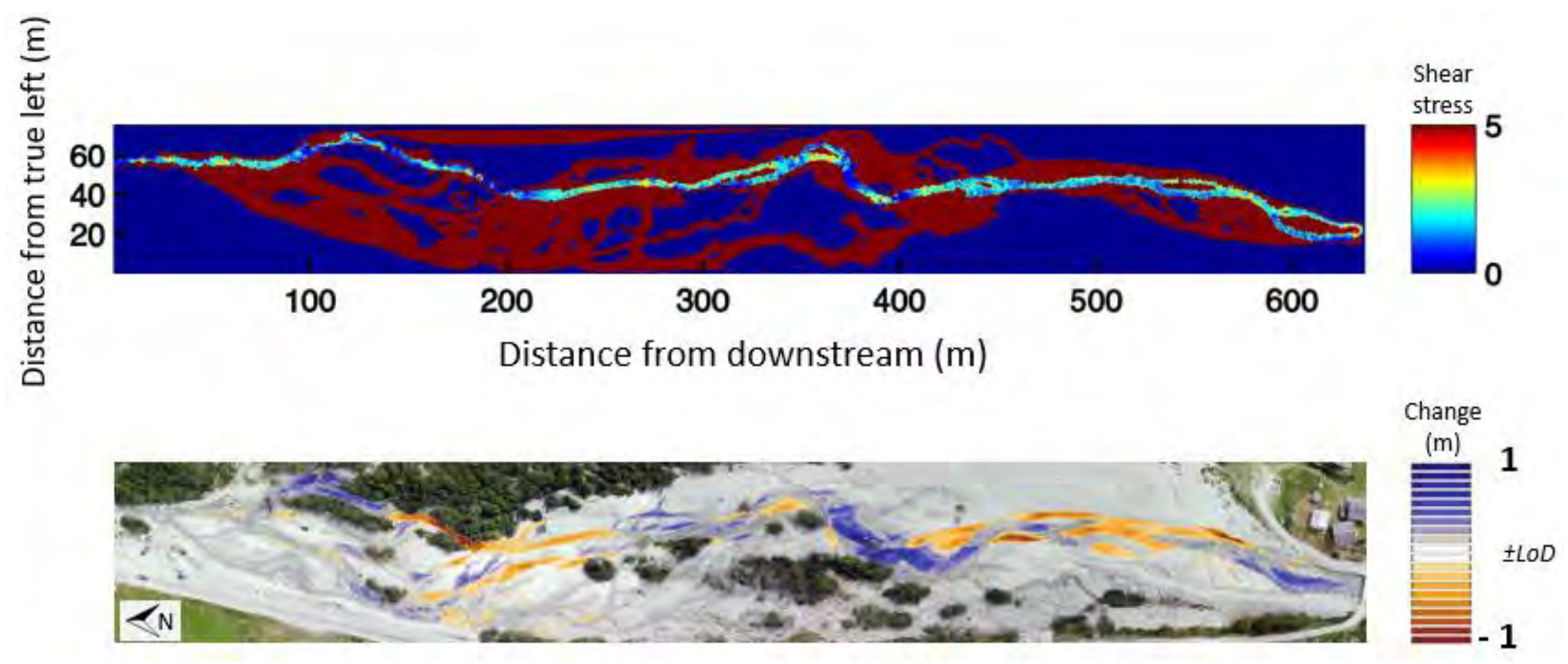


Figure8. 


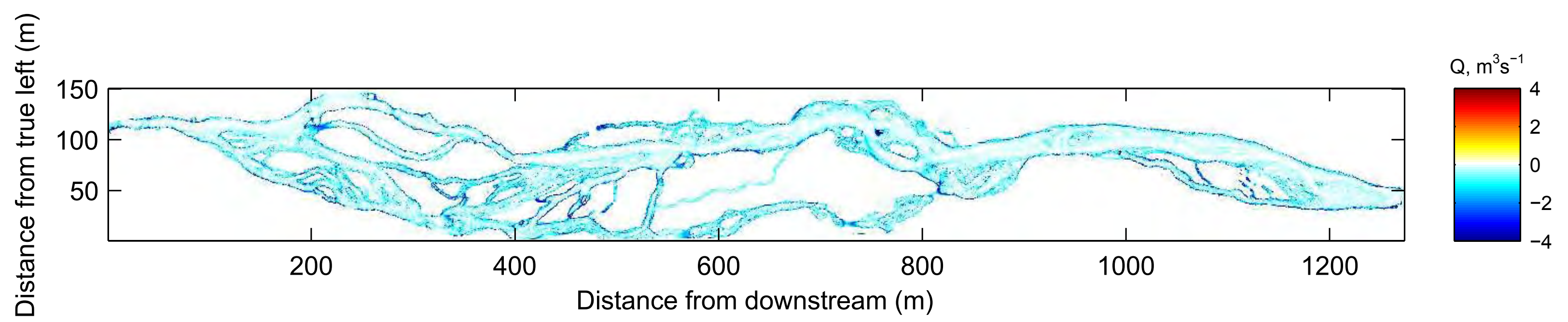

